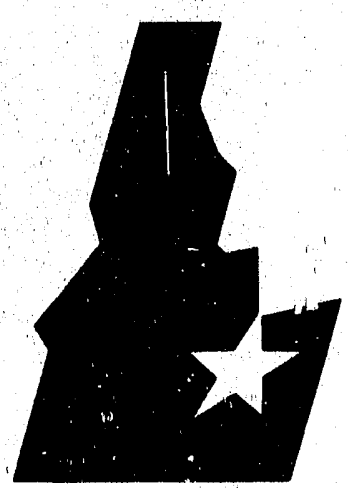

Idaho

National

Engineering

Laboratory

Managed

by the U.S.

Department

of Energy
EGG-WTD-10036

March 1992

INFORMAL REPORT

APR $2 \% 1902$

\section{Assessment of Selected Furnace Technologies for RWMC Waste}

James Batdorf

Robert Gillins

Gary L. Anderson

\title{
$\prod_{\nabla} \operatorname{EST}_{\text {Idano }}$
}

Work performed under

DOE Contract

No. DE-ACO7-761D01570 
This document contains new concepts or the author(s) interpretation of new calculations and/or measurements; accordingly, EG\&G Idaho, Inc. is required by the United States Government to include the following disclaimer:

\section{DISCLAIMER}

This report was prepared as an account of work sponsored by an agency of the United States Government. Neither the United States Government nor any agency theleof, nor any of their employees, makes any warranty, express or implied, or assumes any legal liability or responsibility for the accuracy, completeness, or usefulness of any information, apparatus, product or process disclosed, or represents that its use would not infringe privately owned rights. References herein to any specific commercial product, process, or service by trade name, trademark, manufacturer, or otherwise, does not necessarily constitute or imply its endorsement, recommendation, or favoring by the United States Government or any agency thereof. The views and opininns of authors expressed herein do not necessarily state or reflect those of the United States Government or any agency thereor. 


\title{
Assessment of Selected Furnace Technologies for RWMC Waste
}

\author{
James Batdorf ${ }^{\mathrm{a}}$ \\ Robert Gillins ${ }^{a}$ \\ Gary L. Anderson
}

Published March 1992

\section{Idaho National Engineering Laboratory \\ EG\&G Idaho, Inc. Idaho Falls, Idaho $8341 \mathrm{~s}$}

\author{
Prepared for \\ U.S. Department of Energy \\ Office of Environmental Restoration and Waste Management \\ Under DOE Idaho Field Office \\ Contract DE-AC07-76ID01570
}

a. Science Applications International Corporation, $2300 \mathrm{~N}$. Yellowstone Highway, Idaho Falls, Idaho 83401 
Assessment of Selected Furnace Technologies for RWMC Waste

EGG-WTD-10036

Prepared by:
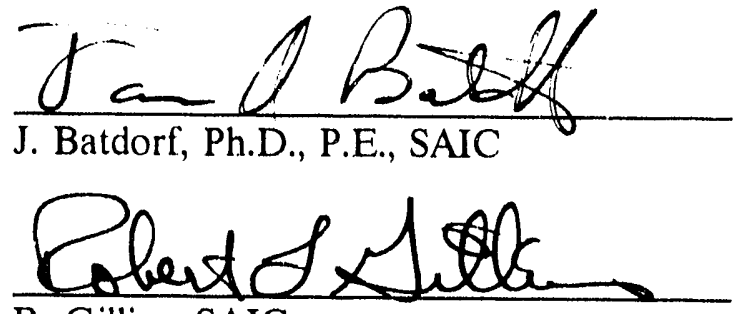

R. Gillins, SAIC
$3 / 11 / 92$

Date

$\frac{3 / 11 / 92}{\text { Date }}$

Reviewed by:
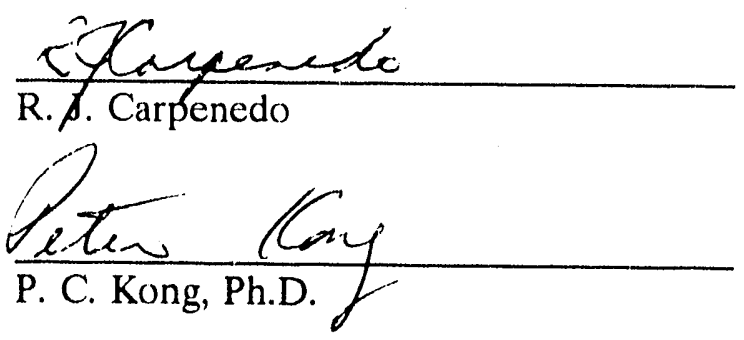

$\frac{\text { Bunt a B entering }}{\text { B. A. Petering }}$

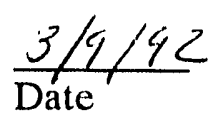

$\frac{3 / 9192}{\text { Date }}$

$\frac{3 / 9 / 92}{\text { Date }^{\prime}}$

Reviewed and Approved by:

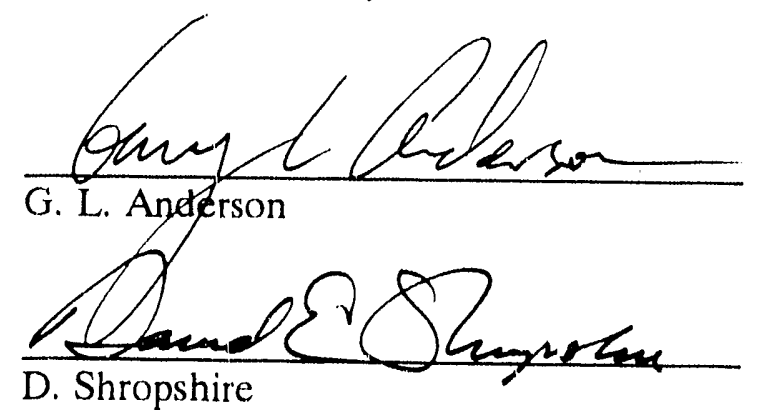

$\frac{3 / 5 / 22}{\text { Date }}$

$\frac{3 / 12 / 92}{\text { Date }}$ 


\section{ABSTRACT}

This report provides a description and initial evaluation of five selected thermal treatment (furnace) technologies, in support of earlier thermal technologies scoping work for application to the Idaho National Engineering Laboratory Radioactive Waste Management Complex (RWMC) buried wastes.

The cyclone furnace, molten salt processor, microwave melter, ausmelt (fuel fired lance) furnace, and molten metal processor technologies are evaluated. A system description and brief development history are provided. The state of development of each technology is assessed, relative to treatment of RWMC buried waste. 


\section{SUMMARY}

In support of the Idaho National Engineering Laboratory (INEL) Thermal Processing Technologies Project this report provides an in-depth description of five selected thermal treatment systems and examines their applicability for treatment of buried waste at the INEL Radioactive Waste Management Complex. The five technologies reviewed are the following: Cyclone Furnace, Molten Salt Processor, Microwave Melter, Ausmelt Lance, and Molten Metal Processor.

A previous report ${ }^{\mathrm{a}}$ provided initial identification and screening of available thermal treatment technologies. This initial screening has been updated in a companion report. ${ }^{b}$ This work and related EG\&G Idaho, Inc. work on buried waste treatment Systems Design Studies ${ }^{c}$ identified both incinerator and melter/incinerator technologies as key components for processing combustible and inert wastes, respectively. This report also identified the need for additional evaluation of the most promising candidate technologies, with emphasis on the melter/vitrifier technologies capable of processing the transuranic (TRU) contaminated inert wastes and soils to produce a high integrity (glass/rock) nonleachable solid final waste form. This report identified electrically heated melters (i.e., Joule Heated, Arc, Plasmas) as leading technologies needing further evaluation. More detailed evaluation of these melters has proceeded and is reported. ${ }^{d}$

This previous thermal screening work identified the five thermal treatment systems technologies described in this report (Cyclone Furnace, Molten Salt Processor, Microwave Melter, Ausmelt lance, and Molten Metal Processor) as also being of considerable potential interest and needing further scoping evaluations against INEL buried waste requirements. This report then presents results of further evaluations. This work describes each technology in terms of its development history, waste processing capabilities, theory of operation, process flowsheet, by-product streams, and material and energy balances. Key advantages, disadvantages, and the state of development of each technology are described. Research, development, and demonstration needs are identified. Lastly, the applicability of the technology to the treatment of the INEL buried waste at the RWMC is summarized.

To assess these technologies, general characteristics of the INEL buried waste are identified. These generalizations are based on the results of the studies noted above and are sufficient for the level of assessment provided herein.

a. R. Gillins, et al., Thermal Technologies for RWMC Wastes, EGG-WTD-9449, EG\&G Idaho, Inc., January 1991.

b. R. Geimer, G. Anderson, et al., An Assessment of Incineration and Melting Treatment Technologies for Application to RWMC Buried Waste, EGG-WTD-10)(35, EG\&G ldaho, Inc., February 1992.

c. J. Mayberry, W. Quapp, F. Feizollahi, et al., Preliminary Systems Designs Study Assessment Report, Vol. II (main report), EGG-WTD-9594-2, EG\&G Idaho, Inc., September 1991.

d. A. Donaldson, R. Capendo, G. Anderson, Melter Development Needs Assessment for RWMC Buried Waste, EGG-WTD-9911, EG\&G Idaho, Inc., Fcbruary 1992. 
For purpose of this assessment the INEL buried waste is generalized into four categories. The first category is a relatively clean combustible waste that is obtained by sorting the total waste stream. The second category is metal sludges, both organic and aqueous based. The third category is a mixture of various noncombustible materials such as bricks, concrete, glass, and dirt. The fourth category is a mixture of the above categories. This last waste category basically assumes that waste recovery operations may be unable to perform substantial waste sorting prior to processing. 


\section{ACKNOWLEDGEMENTS}

This report was prepared for the Waste Technology Department of EG\&G Idaho, Inc., under contract to the U.S. Department of Energy Office of Technology Development Idaho Field Office. Funding was provided under FY-91 Thermal Processing Technologies Technical Task Plan ID-0502-DT, 1991, and ID-040E-2D, 1992. 


\section{CONTENTS}

ABSTRACT $\ldots \ldots \ldots \ldots \ldots \ldots \ldots \ldots \ldots \ldots \ldots \ldots \ldots \ldots \ldots \ldots \ldots \ldots \ldots \ldots \ldots \ldots \ldots$

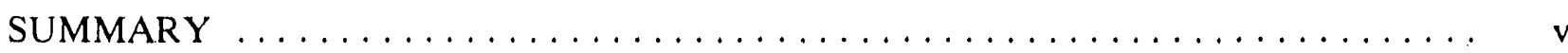

ACKNOWLEDGEMENTS $\ldots \ldots \ldots \ldots \ldots \ldots \ldots \ldots \ldots \ldots \ldots \ldots \ldots$ vii

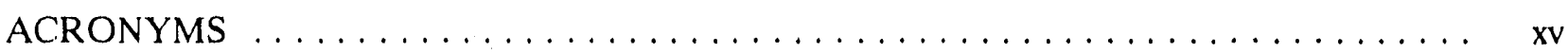

1. CYCLONE FURNACE $\ldots \ldots \ldots \ldots \ldots \ldots \ldots \ldots \ldots \ldots \ldots \ldots \ldots \ldots$

1.1 Development History $\ldots \ldots \ldots \ldots \ldots \ldots \ldots \ldots \ldots \ldots \ldots \ldots \ldots$

1.2 Process Description $\ldots \ldots \ldots \ldots \ldots \ldots \ldots \ldots \ldots \ldots \ldots \ldots \ldots \ldots$

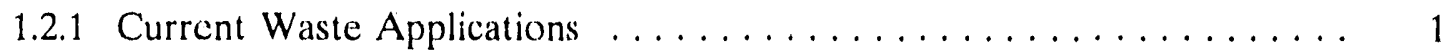

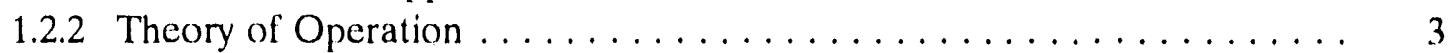

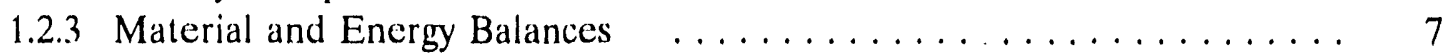

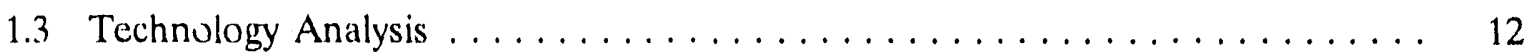

1.3 .1 Advantages . . . . . . . . . . . . . . . . . . . . . 12

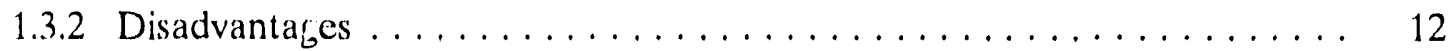

1.3 .3 State of Development . . . . . . . . . . . . . . . . . 13

1.3.4 Research, Development, or Demonstration Needs ............ 13

1.4 Applicability to INEL Buried Waste $\ldots \ldots \ldots \ldots \ldots \ldots \ldots \ldots \ldots \ldots \ldots$

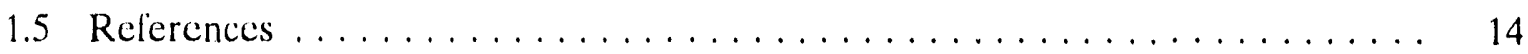

2. MOLTEN SALT PROCESSOR WITH OFFGAS CONDENSATION $\ldots \ldots \ldots$

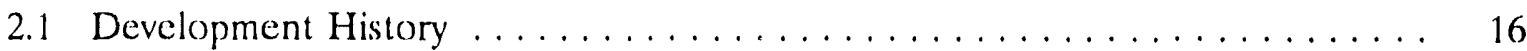

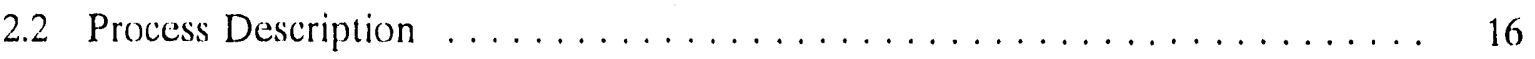

2.2 .1 Waste Applications . . . . . . . . . . . . . . . . . . . .

2.2 .2 Theory of Operation . . . . . . . . . . . . . . . . . . . 18

2.2.3 Material and Energy Balances ..................... 21

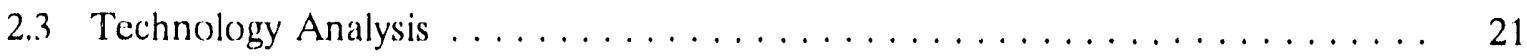

2.3 .1 Advantages . . . . . . . . . . . . . . . . . . . . . . . 21

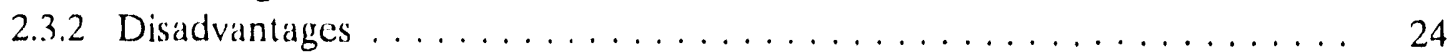

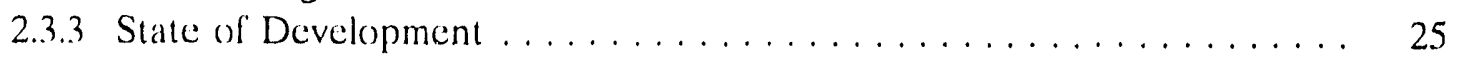


2.3.4 Research, Development, or Demonstration Needs . . . . . . . . . . 25

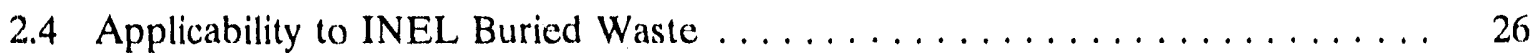

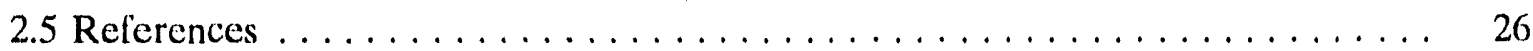

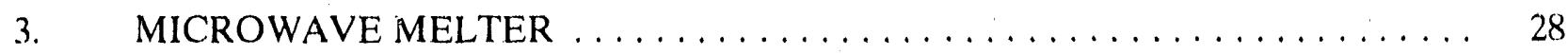

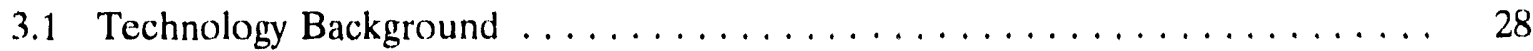

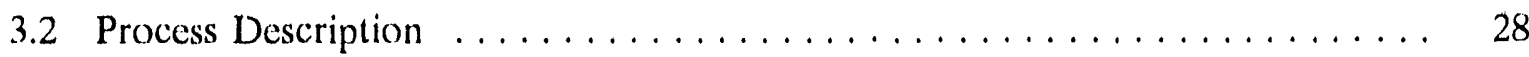

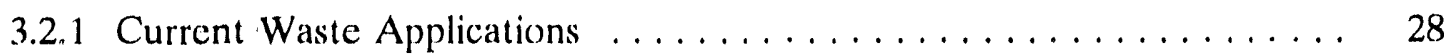

3.2 .2 Theory of Operation . . . . . . . . . . . . . . . . . . . 29

3.2 .3 Material and Energy Balances . . . . . . . . . . . . . . . 31

3.3 Technology Analysis $\ldots \ldots \ldots \ldots \ldots \ldots \ldots \ldots \ldots \ldots \ldots \ldots \ldots \ldots$

3.3.1 Advantages . . . . . . . . . . . . . . . . . . . . 31

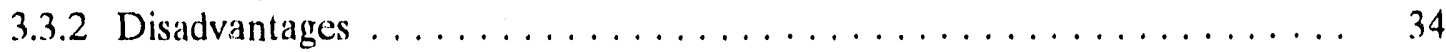

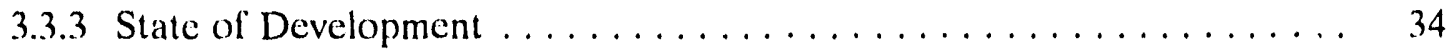

3.3.4 Research, Development, or Demonstration Needs . . . . . . . . . . . 35

3.4 Applicability to INEL Buried Waste $\ldots \ldots \ldots \ldots \ldots \ldots \ldots \ldots \ldots \ldots$

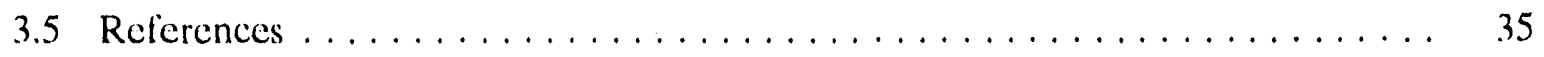

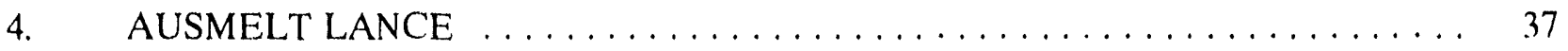

4.1 Development History $\ldots \ldots \ldots \ldots \ldots \ldots \ldots \ldots \ldots \ldots \ldots \ldots \ldots \ldots$

4.2 Process Description $\ldots \ldots \ldots \ldots \ldots \ldots \ldots \ldots \ldots \ldots \ldots \ldots \ldots \ldots$

4.2.1 Current Waste Applications $\ldots \ldots \ldots \ldots \ldots \ldots \ldots \ldots \ldots \ldots \ldots \ldots \ldots$

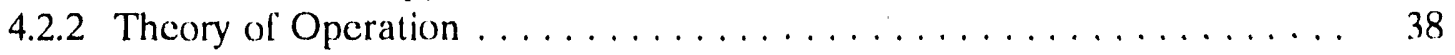

4.2.3 Material and Energy Balances . . . . . . . . . . . . . . 39

4.3 Technology Analysis $\ldots \ldots \ldots \ldots \ldots \ldots \ldots \ldots \ldots \ldots \ldots \ldots \ldots \ldots \ldots$

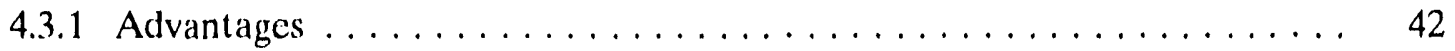

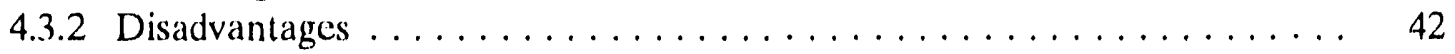

4.3 .3 State of Development . . . . . . . . . . . . . . . . 42

4.3.4 Research, Development, or Demonstration Needs . . . . . . . . . . . . 44

4.4 INEL Buried Waste Applications $\ldots \ldots \ldots \ldots \ldots \ldots \ldots \ldots \ldots \ldots \ldots \ldots \ldots$

4.5 References . . . . . . . . . . . . . . . . . . . . . . . . . 44 
5. MOLTEN METAL BATH TECHNOLOGY $\ldots \ldots \ldots \ldots \ldots \ldots \ldots \ldots$

5.1 Development History $\ldots \ldots \ldots \ldots \ldots \ldots \ldots \ldots \ldots \ldots \ldots \ldots \ldots \ldots$

5.2 Process Description $\ldots \ldots \ldots \ldots \ldots \ldots \ldots \ldots \ldots \ldots \ldots \ldots \ldots$

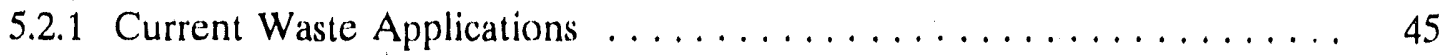

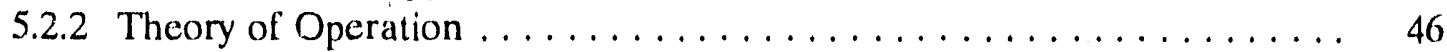

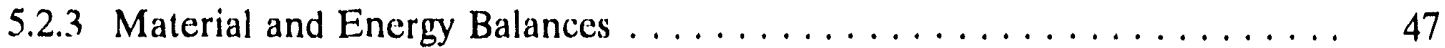

5.3 Technology Analysis $\ldots \ldots \ldots \ldots \ldots \ldots \ldots \ldots \ldots \ldots \ldots \ldots \ldots$

5.3 .1 Advantages $\ldots \ldots \ldots \ldots \ldots \ldots \ldots \ldots \ldots \ldots \ldots \ldots \ldots \ldots$

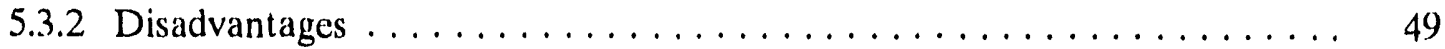

5.3 .3 State of Development . . . . . . . . . . . . . . . . . . . . . 50

5.3.4 Research, Development, or Demonstration Needs . . . . . . . . . . . . . . 50

5.4 Potential for INEL Applications $\ldots \ldots \ldots \ldots \ldots \ldots \ldots \ldots \ldots \ldots \ldots \ldots \ldots$

5.5 References $\ldots \ldots \ldots \ldots \ldots \ldots \ldots \ldots \ldots \ldots \ldots \ldots \ldots \ldots \ldots$

\section{FIGURES}

1-1. Diagram of the B\&W Cyclone Burner and the B\&W Test Facility used for the

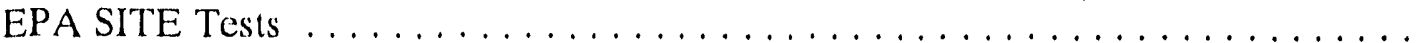

1-2. Arrangement of components in the Vortec Corporation Pilot-Scale Cyclone Melting System

1-3. Illustration of the relative physical size and spatial relationship of the components in the Vortec System

1-4. Simplified schematic of the Pilot-Scale Cyclonic Incineration System at the Institute for Gas Technology test facility

1-5. Graphical illustration of the partioning between the offyas and the slag for cadmium, lead, chromium, and particulate

1-6. Basic process flow diagram for a cyclone waste treatment furnace system . . . . . . . 6

1-7. Graphical representation of the mass flows for a Cyclone Furnace Waste Treatment System, based on data from B\&W 
1-8. Graphical representation of the energy flows for a Cyclone Furnace Waste

Treatment System, based on data from B\&W . . . . . . . . . . . . . . . .

1-9. Graphical representation of the mass flows for a Cyclone Furnace Waste

Treatment System, based on dacia from Vortec, Inc . . . . . . . . . . . . . . 10

1-10. Graphical representation of the energy flows for a cyclone Furnace Waste

Treatment System, based on data from Vortec, Inc

2-1. Overall process concept for molten salt processing of radioactive mixed waste with offgas condensation and salt recycling

2-2. The Molten Salt Process Unit Rockwell International designed $\ldots \ldots \ldots \ldots \ldots \ldots$

2-3. Molten Salt Waste Treatment Process schematic showing Offgas

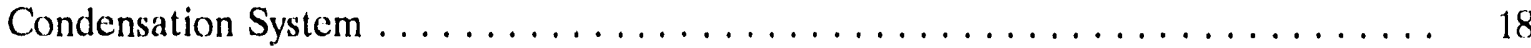

2-4. Process flow schematic for recycle of spent salt $\ldots \ldots \ldots \ldots \ldots \ldots \ldots$

2-5. Simplified process schematic for Molten Salt Processor, Offgas

Condensation System, and Salt Recycle System $\ldots \ldots \ldots \ldots \ldots \ldots \ldots$

2-6. Graphical representation of mass flow for the Process shown in

Figure $2-5$, based on a combustible waste feed $\ldots \ldots \ldots \ldots \ldots \ldots \ldots$

2-7. Graphical representation of the energy flow for the Process shown in Figure 2-5

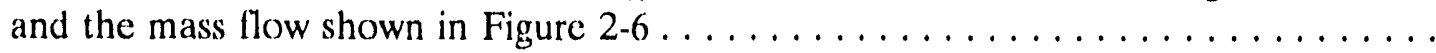

3-1. Process flow diagram for microwave drying and melting of wastewater

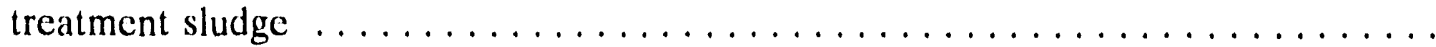

3-2. Mass flow diagram for microwave drying and melting of wastewater

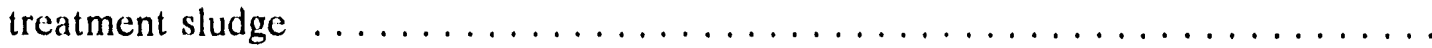

3-3. Energy flow diagram for microwave drying and melting of wastewater

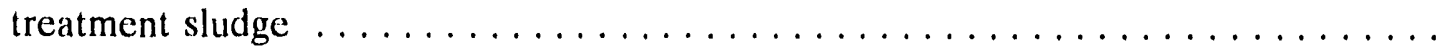

4-1. Schematic cross section of a sirosmelt furnace $\ldots \ldots \ldots \ldots \ldots \ldots \ldots \ldots \ldots \ldots$

4-2. Process flow diagram for a waste treatment system using the $P_{\star}$ usmelt Lance Technology to treat an inert waste stream . . . . . . . . . . . . . . .

4-3. Graphical representation of mass llows for the Ausmelt Lance Furnace using natural gas fuel to process an inert waste $\ldots \ldots \ldots \ldots \ldots \ldots \ldots \ldots$

4-4. Graphical representation of the energy flows for the Ausmelt Lance Furnace using natural gas fuel to process an inert waste $\ldots \ldots \ldots \ldots \ldots \ldots \ldots$ 
5-1. Simplified llow diagram for catalytic extraction process $\ldots \ldots \ldots \ldots$

5-2. Graphical representation of mass flows for a simplified molten metal bath

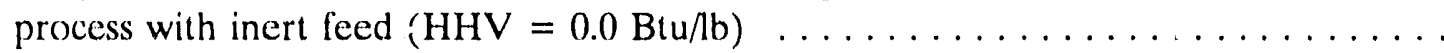

5-3. Graphical representation of energy flows for a simplified molten metal bath

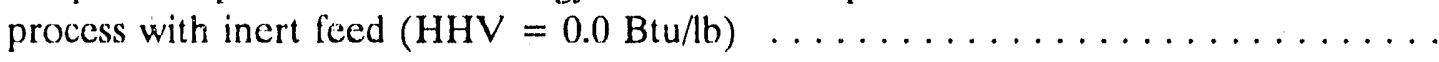




\section{ACRONYMS}

\begin{tabular}{|c|c|}
\hline $\mathrm{B} \& \mathrm{~W}$ & Babcock \& Wilcox \\
\hline CEP & catalytic extraction process \\
\hline DOE & Department of Energy \\
\hline DRE & Destruction Removal Efficiency \\
\hline $\mathrm{EG} \& \mathrm{G}$ & EG\&G Idaho, Inc. \\
\hline EPA & Environmental Protection Agency \\
\hline HEPA & high-efficiency particulate air (filter) \\
\hline INEL & Idaho National Engineering Laboratory \\
\hline ISV & in situ vitrification \\
\hline KFA-KTH & A joint German/Swedish investigation \\
\hline LLNL & Lawrence Livermore National Laboratory \\
\hline MIT & Massachusetts Institute of Technology \\
\hline MMT & Molten Metal Technology \\
\hline PCB & polychlorinated biphenyl \\
\hline PNC & Power Reactor and Nuclear Fuels Development Corporation \\
\hline PVC & polyvinyl chloride \\
\hline PWTF & Plutonium Wastes Treatment Facility \\
\hline RCRA & Resource Conservation and Recovery Act \\
\hline RFP & Rocky Flats Plant \\
\hline RWMC & Radioactive Waste Management Complex \\
\hline SITE & Superfund Innovative Technology Evaluation \\
\hline SisM & Synthetic Soil Matrix \\
\hline
\end{tabular}


TCLP toxicity characterization leaching procedure

TRU transuranic

U.S.S. U.S. Steel 


\section{Assessment of Selected Furnace Technologies for RWMC Waste}

\section{CYCLONE FURNACE}

Several different types of incinerators have been labeled "cyclonic furnace," "vortex furnace," "cyclone furnace," "cyclone melting system," and "cyclonic incineration." These units were designed for sewage sludge incineration, liquid waste destruction, combustion of high inorganic (ash) coal, and use of coal as the primary energy source for glass manufacturing. Originally developed in the 1940s to allow combustion of crushed (not pulverized) coal, the Cyclone Furnace design was suitable for a large variety of fuels and resulted in significantly lower levels of fly ash than combustion of pul rized coal. (Pulverized coal has a very small particle size.) The furnace operates at high temperatures (gas temperatures $>3000^{\circ} \mathrm{F}$ ) to melt ash and form a liquid slag.

\subsection{Development History}

Several U.S. firms are developing this technology for use in the treatment of hazardous wastes. In 1991 the Babcock \& Wilcox (B\&W) Company, Alliance, OH, tested the operation of a cyclone vitrification furnace under the Environmental Protection Agency (EPA) Superfund Innovative Technology Evaluation (SITE) Emerging Technology Program. Figure 1-1 shows a diagram of the $B \& W$ cyclone burner and the layout of the B\&W test facility used in the EPA SITE project tests. ${ }^{1,2}$

Vortec Cornoration, Collegeville, PA, has developed a "Cyclone Melting System," which uses a "Counter-Rotating Vortex" combustor. Originally developed for melting glass, this system has been tested on a hazardous dust containing lead and cadmium. ${ }^{3,4}$ Figure 1-2 illustrates the arrangement of components in the Vortec Pilot Scale Cyclone Melting System. Figure 1-3 illustrates the relative physical size and spatial relationship of the components in the Vortec system.

The Institute of Gas Technology, Chicago, IL, has developed an advanced incinerator based on cyclone combustion. This system has been tested on a variety of liquid wastes. ${ }^{5}$ Figure 1-4 illustrates a simplified schematic of the pilot-scale cyclonic incineration system at the Institute of Gas Technology incineration test facility.

\subsection{Process Description}

\subsubsection{Current Waste Applications}

Cyclone waste treatment furnaces are well suited for processing wastes with high concentrations of inorganic material (e.g., various soil types). Combustion temperatures can exceed $3000^{\circ} \mathrm{F}$, allowing vitrification of relatively high melting point slags. For the furnace to operate properly the ash must have a $\mathrm{T}_{250}$ of $2600^{\circ} \mathrm{F}$ or lower.

The $\mathrm{T}_{250}$ is the temperature at which the ash forms a liquid slag with a viscosity of 250 poise. At this viscosity the slag will just flow on a horizontal surface. Thicker $\left(\mathrm{T}_{250}>2600^{\circ} \mathrm{F}\right)$ slags do not flow through the cyclone furnace and will physically plug the tap hole. 


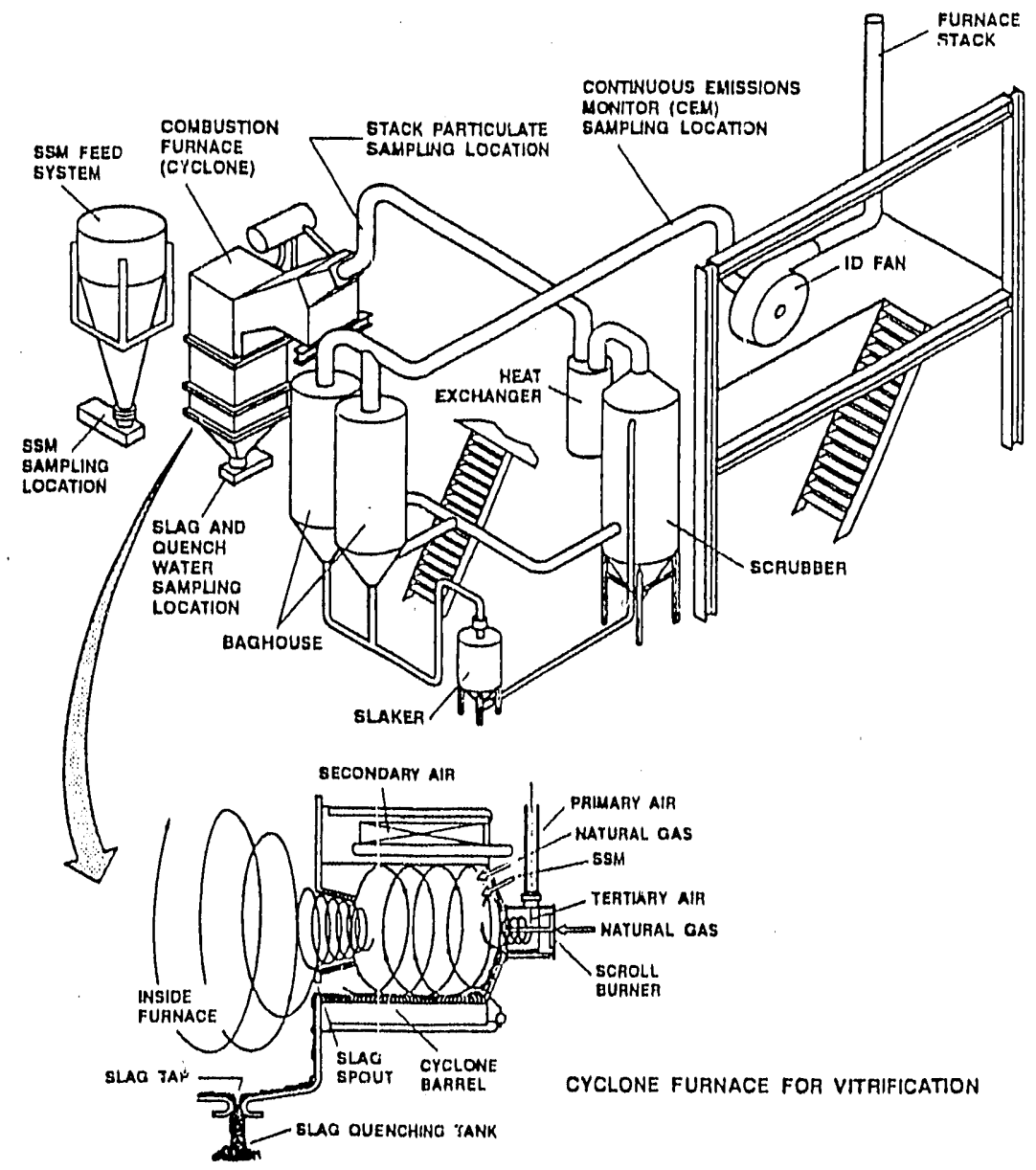

Figure 1-1. Diagram of the B\&W Cyclone Burner and the B\&W Test Facility used for the EPA SITE Tests. ${ }^{1}$

Cyclone furnaces designed for coal combustion range in size from two to three $\mathrm{m}$ in diameter and have a maximum energy release rate of $160 \mathrm{M}$ to $425 \mathrm{M} \mathrm{Btu} / \mathrm{hr}$. For treatment of dry soil this corresponds to a flow rate of nearly 10 tons $/ \mathrm{hr}$.

Before treatment, the waste must be sized and screened to minus $6 \mathrm{~mm}(1 / 4-\mathrm{in}$.), but smaller particles (down to 50 micron) are preferred. Limited test data indicate that $6 \mathrm{~mm}$ (1/4-in.) soil particles may not fully melt. Melting of carbon steel will require operation with a slag temperature exceeding $2800^{\circ} \mathrm{F}$.

B\&W has performed lab scale tests on a synthetic soil matrix (SSM) formulated by the EPA. This soil matrix was spiked with lead, cadmium, and chromium. The soil contained very low levels of organics and had a heating value of $41 \mathrm{Btu} / \mathrm{lb}$. The tests produced a slag that passed the EPA TCLP tests for metals. Total metals analysis indicated that 80-95\% of the chromium remained in the slag, while $65-76 \%$ of the lead and $83-92 \%$ of the cadmium was volatilized into the offgas. Figure 1-5 illustrates this and also shows the split of inert solids between the slag and the fly ash (offgas). The energy required for treating this waste was $6.9 \mathrm{~kW} \mathrm{hr/lb} .^{1,2}$ 


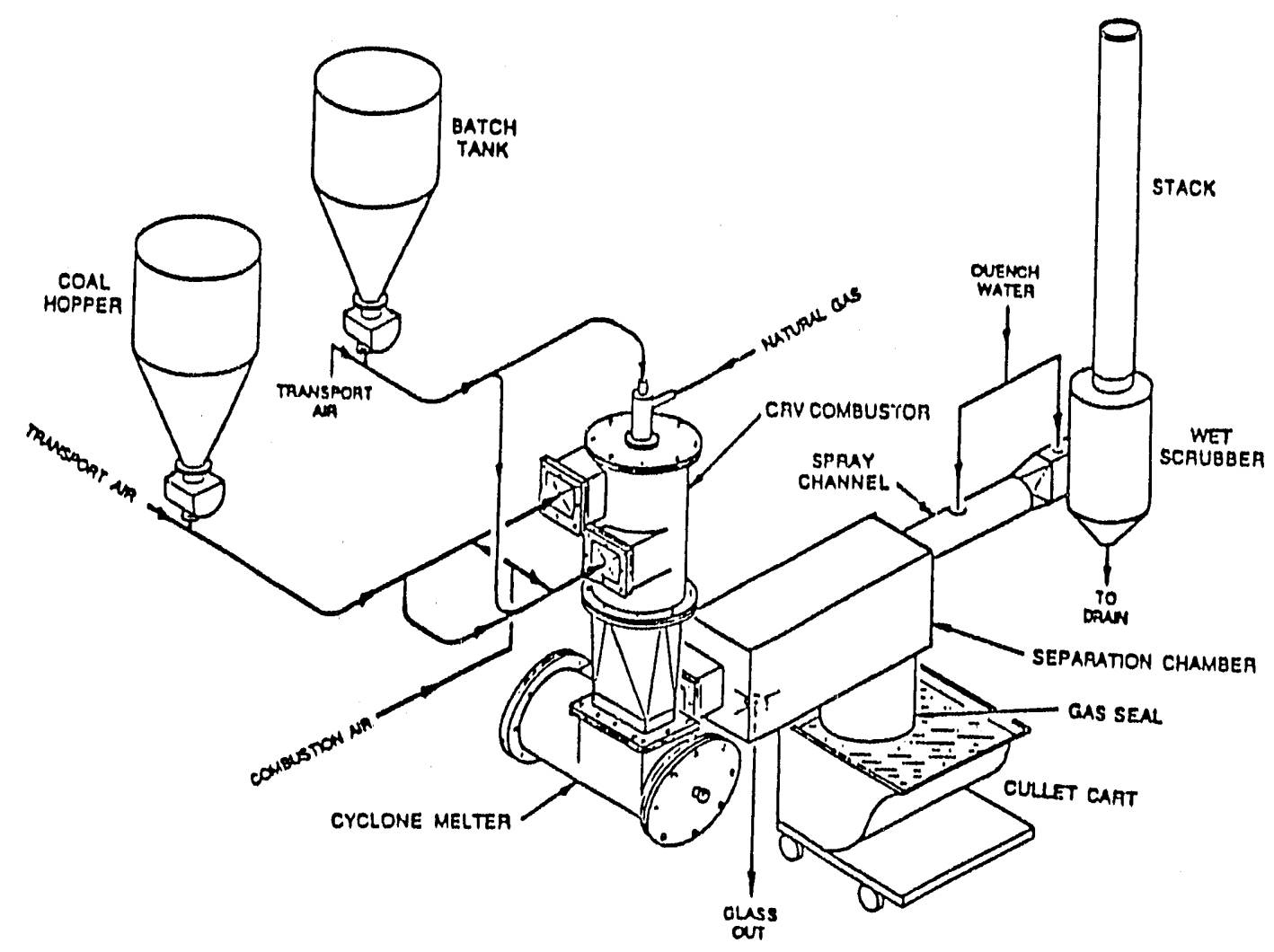

Figure 1-2. Arrangement of components in the Vortec Corporation Pilot-Scale Cyclone Melting System. ${ }^{3}$

Vortec also performed tests on a low heating valuc, solid waste material. The waste material had a heating value of $\leq 1000 \mathrm{Btu} / \mathrm{lb}$ and contained hazardous metals. The slag produced by the process also passed the EPA TCLP test for metals. These tests indicated that $90 \%$ of the lead was volatilized into the offgas. The energy required for treating the waste was $0.7 \mathrm{~kW} \mathrm{hr} / \mathrm{lb}^{3,4}$ This energy requirement is substantially lower than the value reported above for $B \& W$ and is due in part to the differences in waste heating value and part to heat transfer differences from different test sizes and configurations.

The Institute for Gas Technology has performed tests on several liquid feeds including wastewaters with heating values ranging from 1600 to 3000$) \mathrm{Btu} / \mathrm{lb}$, carbon tetrachloride, carbon tetrachloride mixed with hexane, and a low heating value gas. These tests indicated high destruction efficiencies (generally six-9s) of the organics. ${ }^{5}$

\subsubsection{Theory of Operation}

The incinerators discussed in this document use cyclonic flow patterns to enhance combustion of organic materials and to promote melting, agglomeration, and separation of inorganic materials. In this type of incinerator, preheated air $\left(800-11(0)^{\circ} \mathrm{F}\right)$, fuel (natural gas, fuel oil, or powdered coal), and waste material is tangentially injected into a cylindrical furnace chamber. Normally, this cylinder is oriented with a horizontal axis (Figure 1-1). Because preheated air is used, combustion of the 


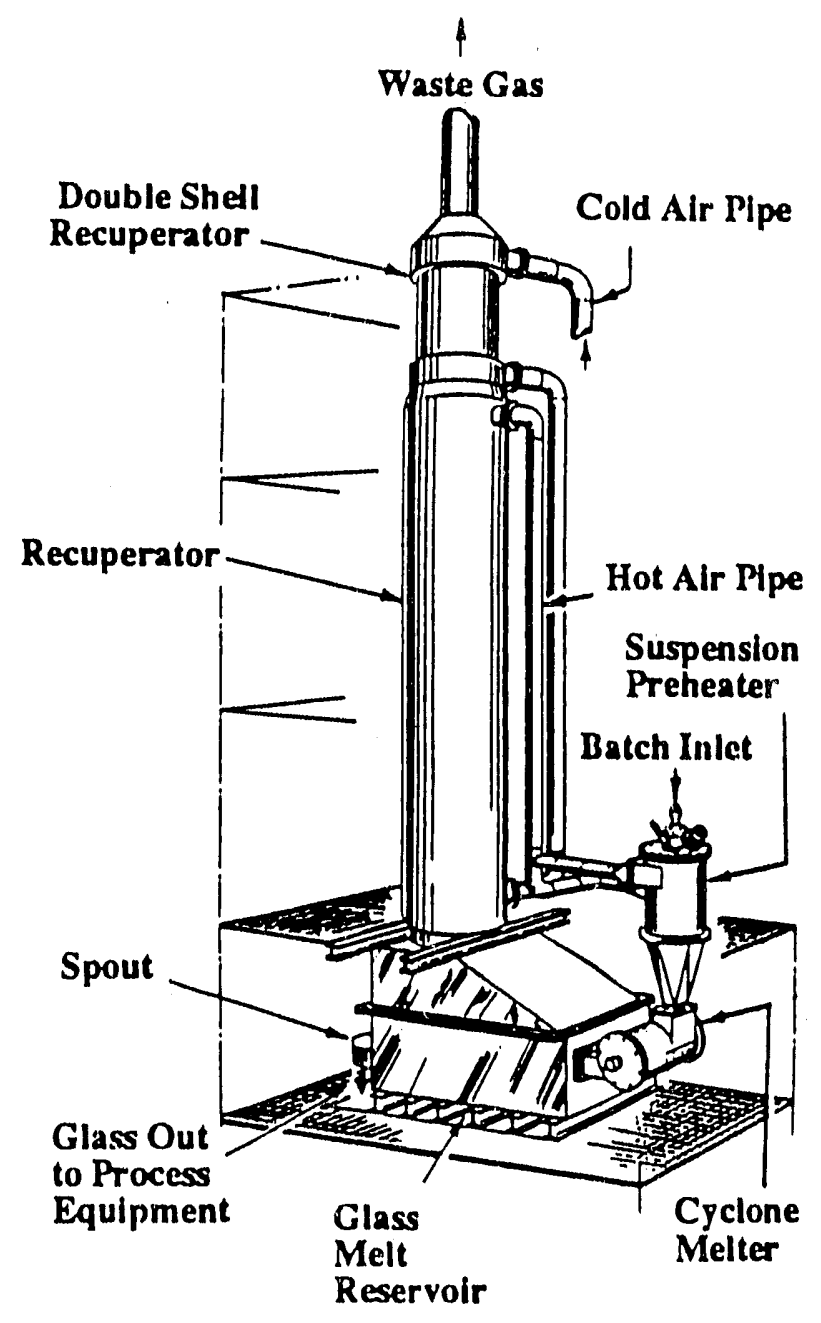

Figure 1-3. Illustration of the relative physical size and spatial relationship of the components in the Vortec System. ${ }^{4}$

waste and fuel occurs at elevated temperatures and the process operates at temperatures up to $3000^{\circ} \mathrm{F}$, although a typical operating temperature is $2600^{\circ} \mathrm{F}$. Under these conditions the inorganic components of the feed materials are melted and transported to the outer walls of the cylinder. The molten inorganic material (slag) flows down the reactor walls and is tapped from the bottom of the reactor. Typically, the molten slag is quenched and collected in a water bath. Combustion of the organic feed components may occur in either 1 or 2 stages. In some designs the organics are partially combusted and gasified in the primary stage and subsequently fully oxidized in a secondary combustion chamber. These stages may occur in two different chambers with separate burners and air feeds or in one chamber with one burner and multiple air inlet ports.

Figure 1-6 shows a process flow diagram for a typical cyclone furnace. Waste material and additives (solid fuel or material to lower the slag viscosity) are introduced to the cyclone furnace by air transport. Combustion air is preheated and introduced to the cyclone furnace. Depending on the heating value of the waste material, supplemental fuel may also be added to the furnace. Recuperators, which are gas to gas heat exchangers that transfer heat from exhaust gases to the inlet 

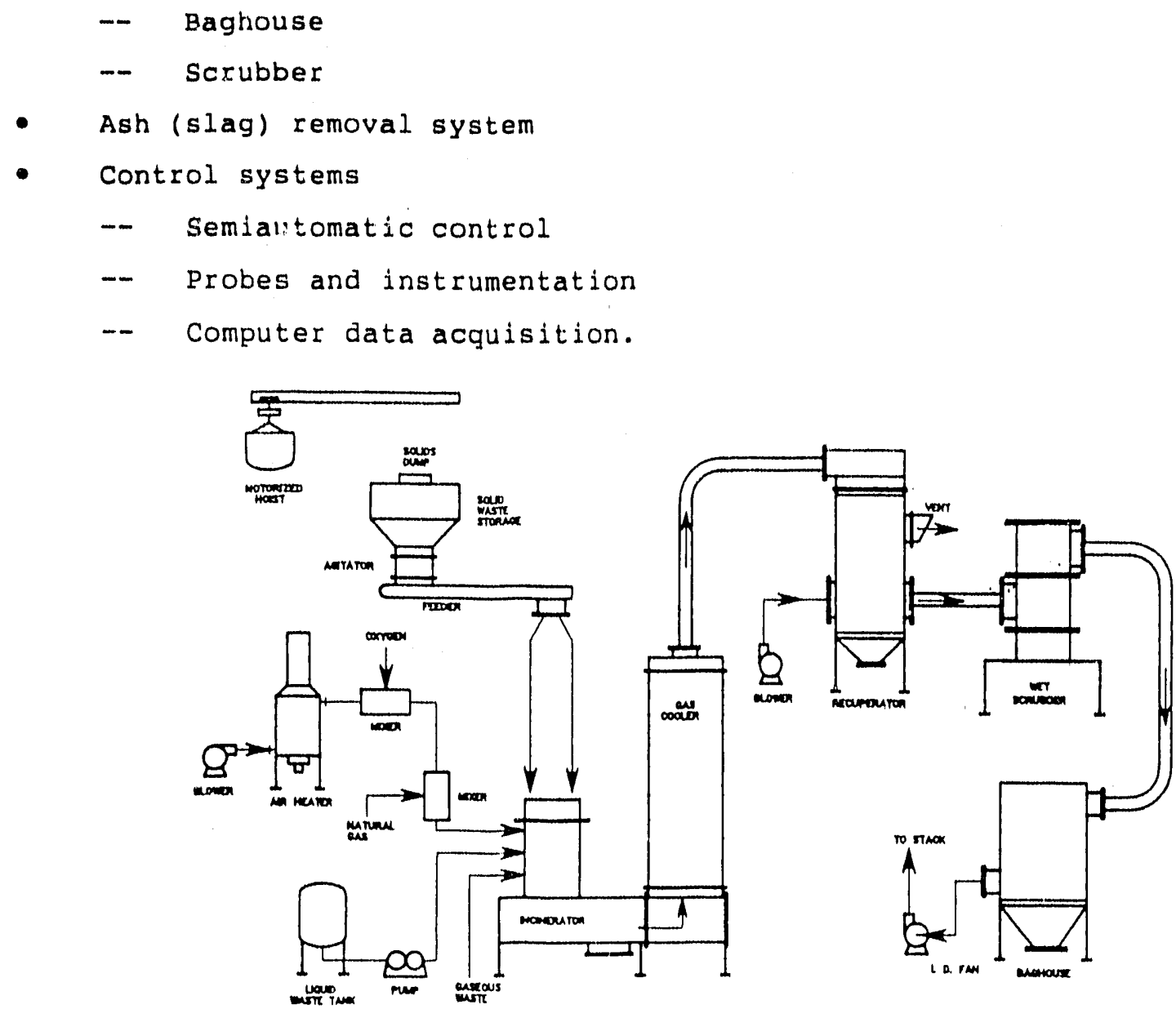

Figure 1.4. Simplified schematic of the Pilot-Scale Cyclonic Incineration System at the Institute for Gas Technology test facility. ${ }^{5}$

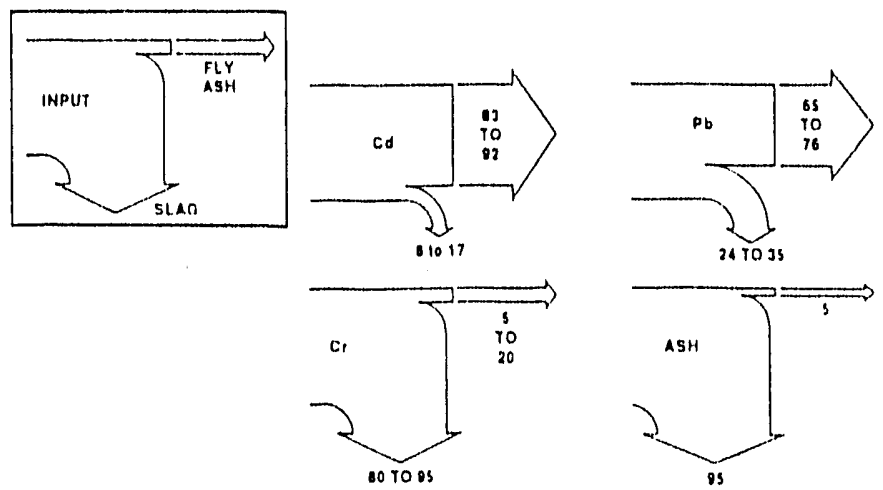

Figure 1-5. Graphical illustration of the partioning between the offgas and the slag for cadmium, lead, chromium, and particulate. 


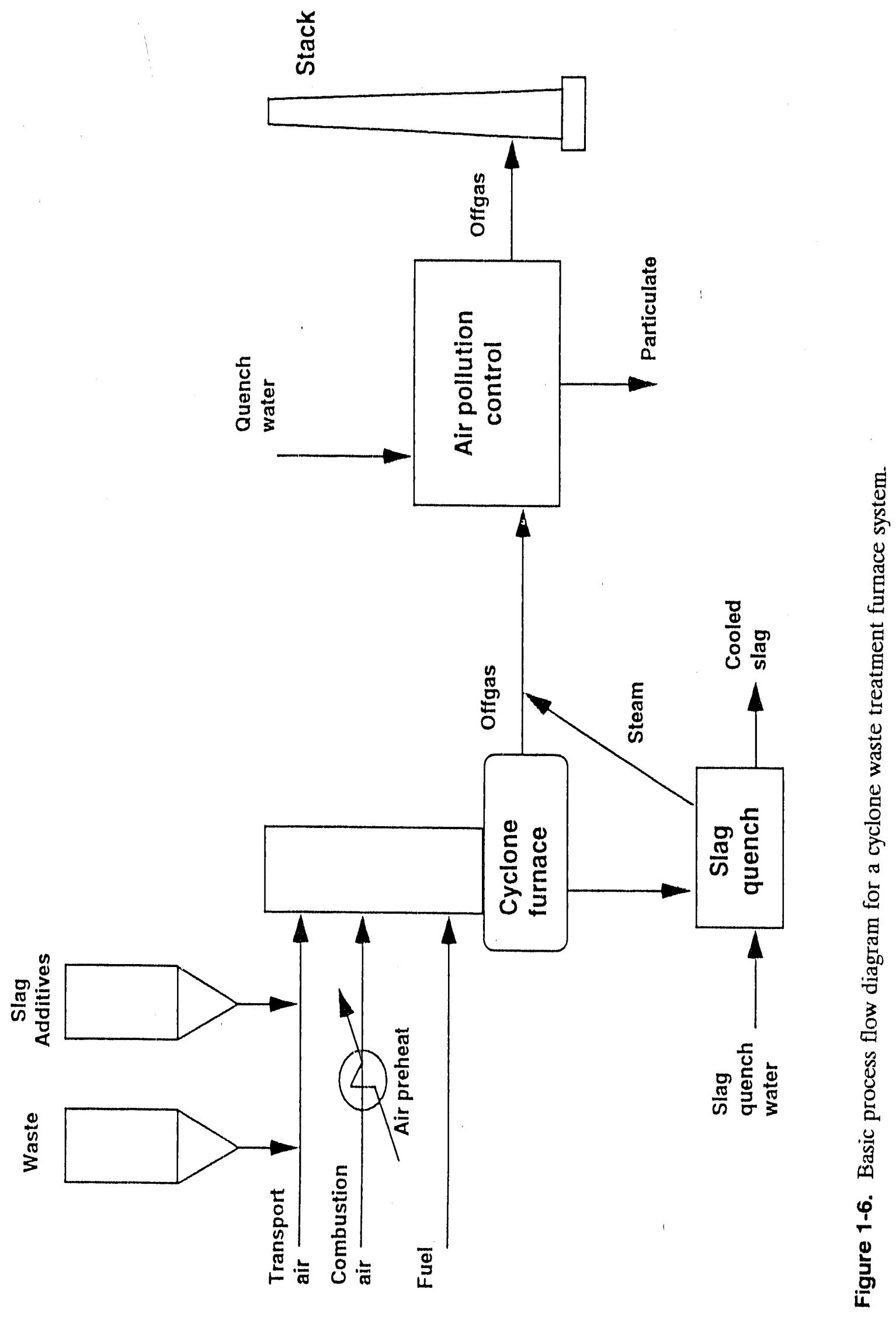


air, are typically used to supply the energy for the air preheat. For the sake of simplicity, this is not shown in Figure 1-6. Also, the potential contamination and criticality problems associated with the offgas of a radioactive waste incinerator detract from the desirability of recuperator use. Steam and gases generated from the slag quench have been added to the offgas flow prior to the offgas treatment system. Details of the offgas treatment system are not shown in Figure 1-6. Again, for the sake of simplicity, the particulate is assumed to be removed as a dry product with $10(0 \%$ efficiency. Quench water is added to provide an adiabatic quench of the offigas.

This process results in the generation of three secondary waste streams. By-products of the process are a solidified slag, slag quench water, and offgas.

Solidified Slag - The slag is produced from melting 93-97\% of the inert feed material. The remainder is entrained into the offgas. Depending on the slag composition and the completeness of the melting process, this slag can provide a very good quality waste form that readily passes EPA leach tests for toxicity.

Slag Quench Water - The molten slag is poured into a water filled tank where it is cooled and solidified. This water and any sludge that accumulates in the tank will require periodic removal and treatment. This waste stream is expected to be very small and most likely can be blended back into the feed.

Offgas - The offgas from this process has a high particulate loading, 3-7\% of the inert feed material. This particulate loading is caused by a combination of sizing the feed to less than $1 / 4$ in., and using high velocities in the combustor which enhance entrainment. Further, operating at high temperatures will result in the volatilization and carryover of high vapor pressure metals such as cadmium and lead. The use of combustion air preheat and high process temperatures also results in the formation of high levels of nitrogen oxides (typically several hundred ppm). As with any combustion process, halogens and sulfer present in the feed can react with hydrogen and form a id gases.

\subsubsection{Material and Energy Balances}

Figures 1-7 through 1-10 illustrate material and energy flows for the process flow diagram shown in Figure 1-6. These material and energy balances were prepared using a very similar basis-a waste feed input of $1000 \mathrm{lbs} / \mathrm{hr}$ of primarily inert material with minimal heating value.

Figures 1-7 and 1-8 were prepared using information published by $B \& W^{1,2}$ The primary energy balance is based on the use of $4.75 \mathrm{M} \mathrm{Btu} / \mathrm{hr}$ to treat 20() $\mathrm{lb}(\mathrm{s}) / \mathrm{hr}$ of soil. The waste transport air flow rate was assumed to be $3 \%$ of the total mass flow rate of combustion air. The slag quench water flow rate was sized to cool the slag to the boiling point of water by vaporizing water, actual operation would require a slightly higher llow rate or external cooling. The steam generated from cooling the slag was vented to the offgas treatment system. The offgas quench water flow rate was calculated by assuming that $960 \mathrm{Btu} / \mathrm{lb}$ of energy was transferred from the water to the offgas, and that the offgas temperature was reduced to 18()$^{\circ} \mathrm{F}$. This is a simple approximation that corresponds to an adiabatic quench process. Fly ash entrained in the offyas was calculated as $5 \%$ of the total solid feed rate. 


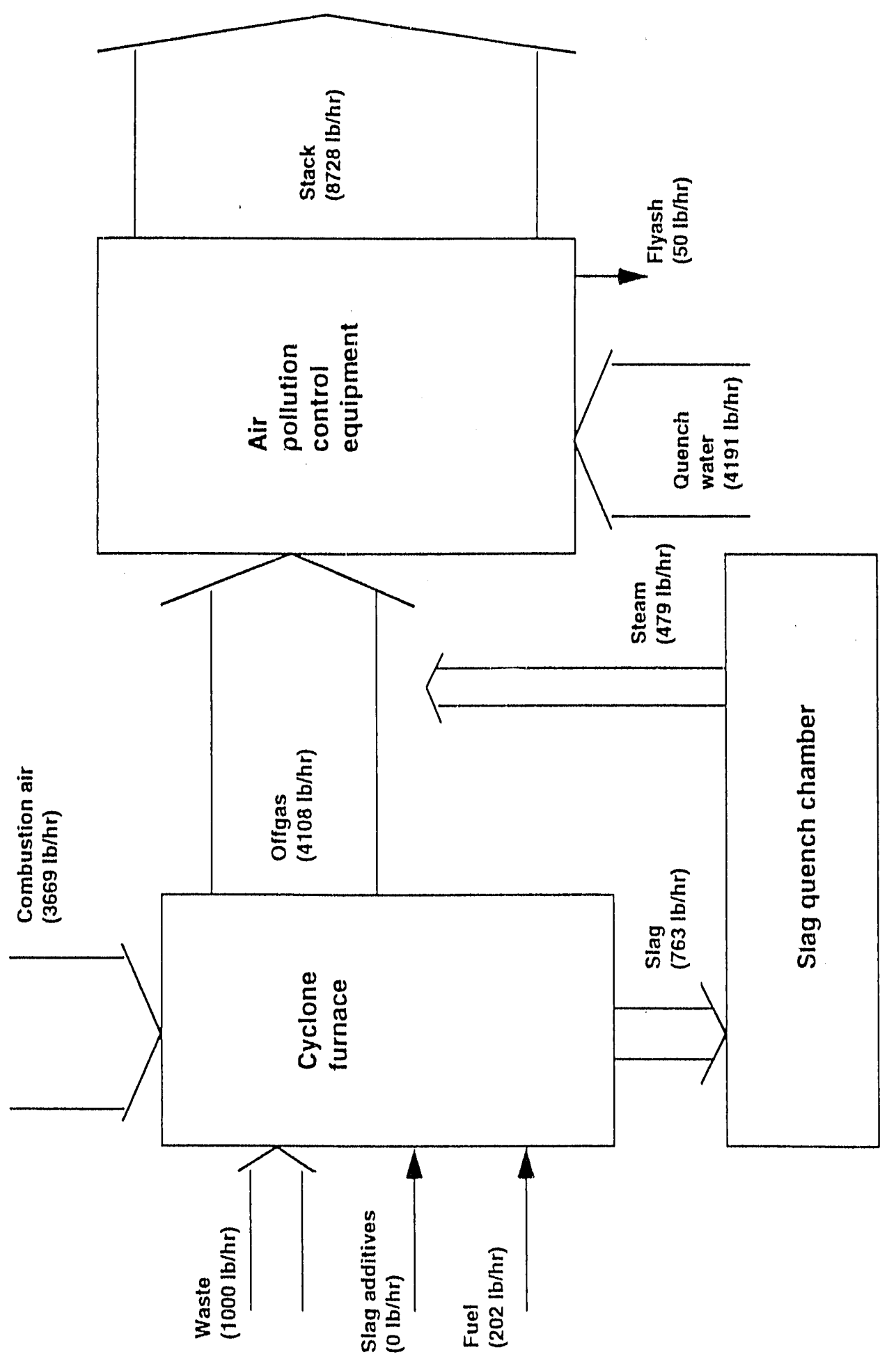

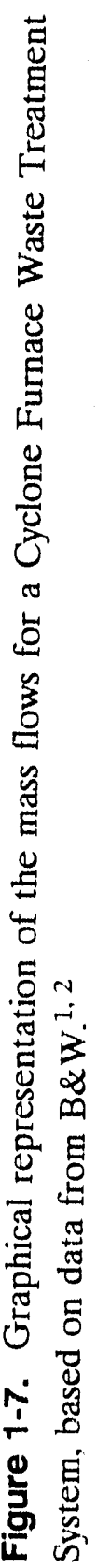




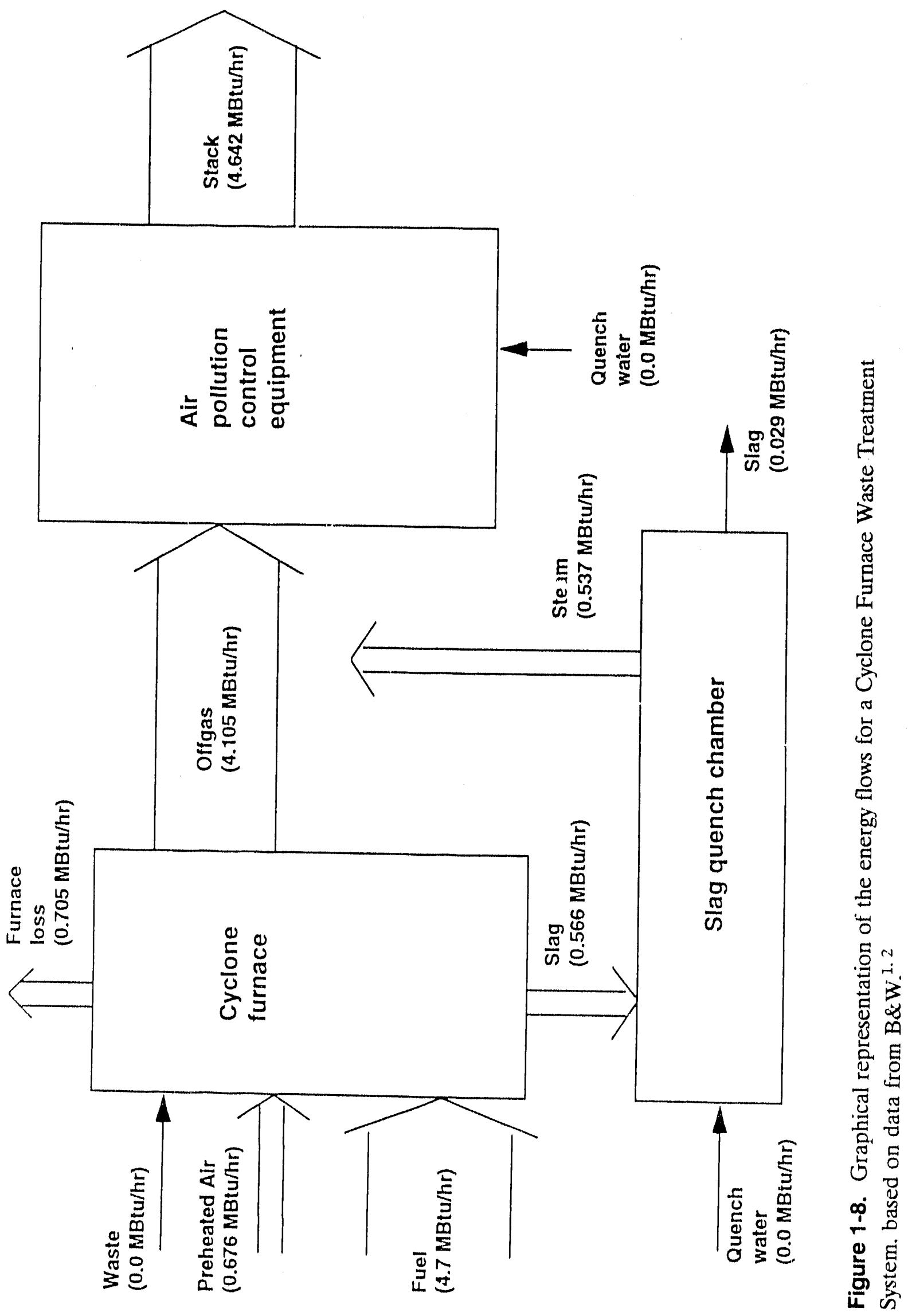




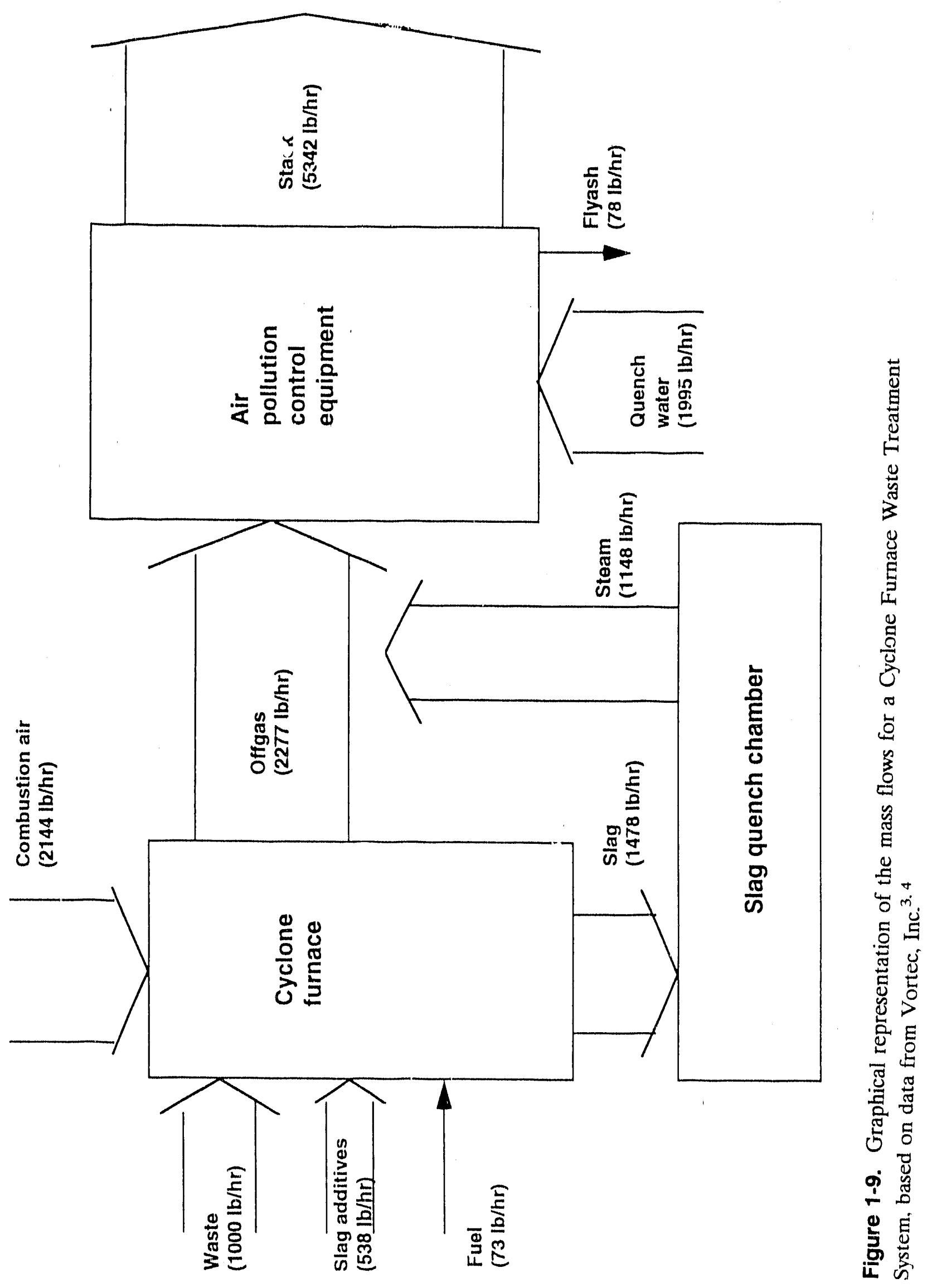




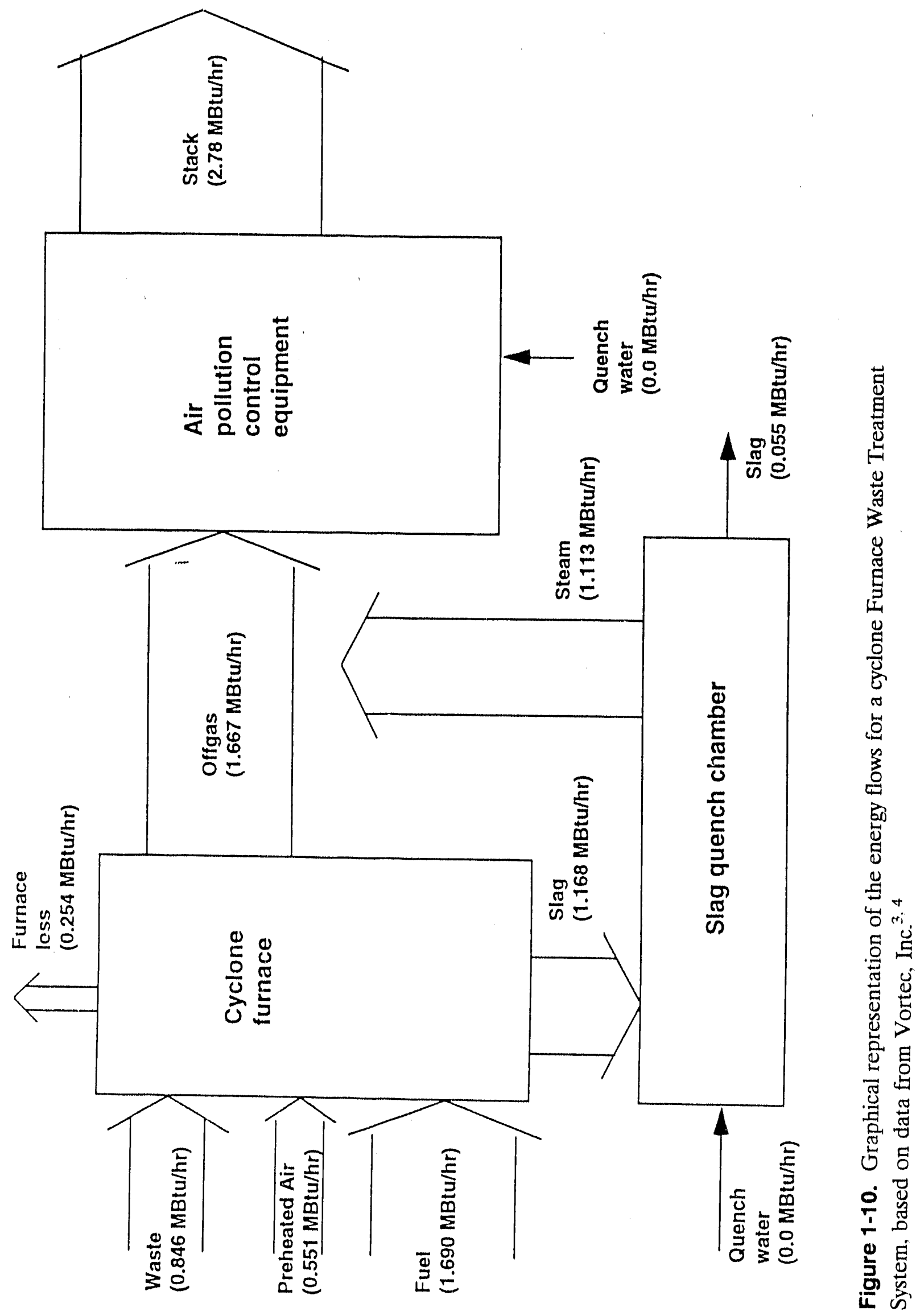


Figures 1-9 and 1-10 were prepared using information prepared by Vortec Corporation. ${ }^{3,4}$ The primary energy balance is based on the use of $1.1 \mathrm{M} \mathrm{Btu} / \mathrm{hr}$ to treat $940 \mathrm{lbs} / \mathrm{hr}$ of feed material. This feed material consists of $65 \%$ flue dust containing $6 \%$ carbon and $35 \%$ slag forming additives. The slag quench and water quench were computed as described for Figure 1-8. Fly ash entrainment was $3 \%$ of the solid feed.

Comparing Figure 1-8 and Figure 1-10, it is apparent that these two processes have greatly different energy requirements. Figure $1-8$ indicates an energy use of $6.9 \mathrm{~kW} \mathrm{hr/lb}$, while Figure $1-10$ indicates an energy use of $0.7 \mathrm{~kW} \mathrm{hr} / \mathrm{lb}$. This variation is extremely interesting, both energy use numbers are based on actual operating data, both systems are operating on similar feedstocks, and both systems use the same (or at least very similar) technology. There is not an obvious reason for this discrepancy. B\&W (the high number) may have simply been operating at a point very far from optimum. The Vortec unit would appear to be operating very efficiently. Theoretical energy requirements are approximate $0.5 \mathrm{~kW} \mathrm{hr/lb}$.

\subsection{Technology Analysis}

\subsubsection{Advantages}

The cyclone furnace operates at high temperatures, has high levels of turbulence, and sufficient residence time to achieve highly efficient destruction of organics. The high temperature operation results in vitrification of solids and produces a slag that is likely to be a highly stable waste form. Large cyclone furnaces have been built and operated during the past 50 years. This operating experience will assist in developing a waste treatment system based on this technology.

\subsubsection{Disadvantages}

The are several disadvantages that are typical of any high temperature process. The combustion air preheat and high temperature operation results in high levels of $\mathrm{NO}_{\mathrm{x}}$ in the offgas. The high temperatures also volatilize some heavy metals, the limited data indicates that $90 \%$ of the cadmium, $75 \%$ of the lead, and $20 \%$ of the chromium in the feed will be transported into the offgas. High levels of volatile metals carryover are probable for any high temperature and high gas flow process that results in a vitrified product.

The high level of turbulence and small leed particles result in entrainment of significant quantities of particulates in the offgas (fly ash is roughly $3-7 \%$ of the solid leed).

Practical operation requires a relatively low viscosity slag $\left(\mathrm{T}_{250}<2600^{\circ} \mathrm{F}\right)$. In order to achieve the desired slag viscosity it is often necessary to blend the feed with flux additives that lower viscosity for a given temperature such as silica, calcium oxide, calcium carbonate, sodium or potassium oxide, etc.

In order to achieve the high furnace temperatures, it is necessary io preheat the combustion air to a temperature range of 800$)-1100^{\circ} \mathrm{F}$. In a coal combustion system this is accomplished by heat exchange with the exhaust gases. This is probably not practical for a radioactive waste treatment process. Heat exchangers on the offgas stream of a waste treatment process are more prone to fouling and require more maintenance than heat exchangers in a fossil fuel combustion process. This 
fouling is caused by a greater concentration of contaminants in the feed, variability of the feed, and higher operating temperatures that increase the degree of metals volatilization. This fouling is particularly undesirable in radioactive waste treatment processes. Design considerations for control of criticality and contamination will probably outweigh the need for energy cost savings.

\subsubsection{State of Development}

Cyclone furnaces for the combustion of coal and other fuels have been in commercial operation for many years. There are hundreds of installations with single furnace sizes up to $425 \mathrm{M} \mathrm{Btu} / \mathrm{hr}$. Cyclone furnaces for waste treatment are currently in the development stage. However, because of the maturity of the base technology, progression to operating installations should proceed very rapidly.

\subsubsection{Research, Development, or Demonstration Needs}

Research is needed to fully characterize the slag that can be expected by this process. This information is essential for several reasons, for example: determining the quantity and types of additives needed to produce proper melt conditions for processing and final product performance is required to develop a complete process economic analysis; the characteristics of the slag and additives will be required to determine acceptable types of refractory and the expected refractory life; and the variability of leach rates with slag composition will indicate the degree of control (feed material screening, testing, etc.) necessary to ensure that the final waste form meets quality objectives.

Slag Characterization - Slag produced by this process (as well as any vitrification process) is a combination of the inert components in the combustible waste (e.g., the ash fraction of paper and wood) and any noncombustible material in the feed (soil, glass, metal, etc.). Research needs to address the following questions:

- What slag composition is expected from the processing of various DOE waste streams? A consideration is whether oxidation of metals in the process significantly contributes to the slag composition.

- What are the physical properties of the slags produced by thermally treating these waste streams? Specifically, what is the melting point, heat capacity, heat of fusion, and viscosity?

- Will these slags pass the EPA toxicity tests? Are they sufficiently nonleachable to immobilize the transuranic elements?

- What additives should be considered to improve the physical properties? What additives should be considered to improve the leaching resistance?

- What refractories are compatible with these slags under the process conditions anticipated during treatment?

Feed Preparation - What feed preparation is required to meet the needs of a cyclone incinerator? Is this type of pretreatment feasible for radioactively contaminated waste of the composition being 
examined? What if the waste also includes transuranic elements? What fraction of the waste will be able to be prepared in such a manner as to be acceptable to this process?

\subsection{Applicability to INEL Buried Waste}

The cyclone furnace is best suited for the treatment of the inert wastes. Treatment of these wastes will require significant crushing and grinding followed by size classification to ensure correct particle size distribution. INEL soil has a $\mathrm{T}_{250}$ that exceeds $3000^{\circ} \mathrm{F}$. Tests conducted under the ISV Program ${ }^{8}$ indicated that typical INEL soil has a viscosity of $4000-5000$ poise at $2900^{\circ} \mathrm{F}$. INEL soil mixed with $5 \mathrm{wt} \%$ sodium oxide $\left(\mathrm{Na}_{2} \mathrm{O}\right)$ had a viscosity of about 500 poise at $2900^{\circ} \mathrm{F}$. Mixtures of INEL soil and buried waste may result in slags with higher or lower viscosity.

The cyclone furnace also may be useful in treating some INEL sludge streams. The aqueous sludges may be treated by using an auxiliary fuel. Because the aqueous sludges are primarily inert, they will produce a significant quantity of slag. Blending with slag additives may be required to obtain the desired slag characteristics. The organic sludges can be readily treated, again blending may be required to adjust the slag chemistry. Evaporation salts with high concentration of nitrates will result in the formation of significant quantities of $\mathrm{NO}_{\mathrm{x}}$. These salts should probably not be treated in a thermal process.

The combustible waste stream should not be treated in the cyclone furnace. Pretreatment of this waste to achieve a very finely divided feed material will be very difficult. This process does not offer significant advantages for treating a standard solid combustible waste stream.

The mixed waste stream will have a high inert component and may be considered for this process. However, the solid organic fraction may interfere with pretreatment and make it difficult to obtain a stream that can be fed to this unit without plugging the feed system.

\subsection{References}

1. J. M. Czuczwa, H. Farzan, S. J. Vecci, and J. J. Warchol, "Cyclone Furnace for Vitrification of Contaminated Soil and Wastes," 1991 Incineration Conference, Knoxville, Tennessee, May 13-17, 1991, Proceedings, pp. 613-620.

2. The Babcock \& Wilcox Company, Cyclone Furnace for Waste and Treatment of Contaminated Soil - Phase I, Final Report Prepared for the U. S. Environmental Protection Agency, Risk Reduction Engincering Laboratory, March 1991.

3. J. G. Hnat, W. F. Olix, W. F. Talley, and L. M. Bartone, "A Cyclone Melting System for Processing Hazardous Waste Dusts," National Research \& Development Conference on the Control of Hazardous Materials, February 20-22, 1991.

4. J. G. Hnat, W. F. Talley, L. M. Bartone, and P. T. Myles, "Cyclone Melting System Adds Options for Glass Producers," Ceramic Industry, April 1990, pp. 62-63. 
5. Mark J. Khinkis, Destruction of Industrial Waste Via Cyclonic Incineration, Distributed at the Third Annual Hazardous Materials ' 90 Management Conference, Rosemont, Illinois, March 13-15, 1990, Report prepared by the Institute of Gas Technology, Chicago, Illinois.

6. William S. Rickman, CRC Handbook of Incineration of Hazardous Wastes, Boston: CRC Press, Inc., 1991, pp. 252-253.

7. R. J. McCormick, R. J. DeRosier, K. Lim, R. Larkin, and H. Lips, Costs for Hazardous Waste Incineration, Park Ridge, New Jersey: Noyes Publications, 1985, page 101.

8. J. L. Buelt, C. L. Timmerman, K. H. Oma, et al., In Situ Vitrification of Transuranic Waste: An Updated Systems Evaluation and Applications Assessment, Pub. No. PNL-4800, Supplement 1, UC-70, Pacific Northwest Laboratory, Richland, WA, March, 1987. 


\section{MOLTEN SALT PROCESSOR WITH OFFGAS CONDENSATION}

\subsection{Development History}

During the 1970s, the Atomics International Division of Rockwell International investigated the use of molten carbonate salts for industrial applications. These applications included the use of molten salt as a chemical offgas scrubber for acid gases, as a reaction medium for combustion of high sulfur fuels, and as a reaction medium for gasification processes. Rockwell built and operated a pilot plant to demonstrate the molten salt process for combustion of coal. ${ }^{1}$ Bench scale and pilot scale tests also were conducted on a varicty of simulated waste materials including glove-box tests with actual uranium and plutonium. ${ }^{2,3}$

Lawrence Livermore National Laboratory (LLNL) and Rockwell are developing a molten salt process with offgas condensation for the destruction of radioactively contaminated toxic wastes. ${ }^{4}$ Figure 2-1 illustrates the overall concept of radioactive and mixed waste treatment in a molten salt processor with offgas condensation. The process is being developed for a wide range of wastes including paper, plastic, rubber, halogenated organics, oils, greases, and aqueous streams containing minor organic fractions. Waste materials are sized (e.g., crushed, ground, or shredded), mixed with oxygen and supplemental fuel as needed, and injected into a bed of molten salt. The molten salt bed consists of a mixture of alkali or alkaline earth carbonates and halides. A typical starting composition is $90 \%$ sodium carbonate and $10 \%$ sodium chloride or spdium sulphate. The molten salt bed is maintained at temperatures ranging from 800 to $10500^{\circ} \mathrm{C}$.

Oxygen reacts with the fuel and waste, decomposing the waste and releasing energy, which is transferred to the molten salt. A closed loop gas cooling circuit removes this energy from the reactor walls. Gases released by the combustion reactions percolate through the molten salt bed and are transported to the offgas treatment system. Figure 2-2 illustrates the molten salt process unit Rockwell designed.

The system LLNL is developing includes a hold, test, and release offgas system. This type of offgas system is not required with molten salt technology, but can be more easily implemented with molten salt technology. This offgas treatment system consists of a closed loop heat exchanger, a series of filters, and a condensation system. The three-step condensation system consists of first a water condenser, then gas dryer towers, and last a carbon dioxide condenser. The remaining offgas (primarily nitrogen and oxygen) is recycled back to the reactor. A small fraction of this recycle stream is vented to prevent a buildup of these gases. ${ }^{5}$

\subsection{Process Description}

\subsubsection{Waste Applications}

Treatable waste streams include cellulosic matter, rubber and plastics, organohalogen solvents, oils and greases, and aqueous streams containing low concentrations of organics. In the late 1970s, bench-scale tests were conducted on a large variety of wastes including polyvinyl chloride (PVC), simulated radwaste (a blend of high ash paper, Kimwipes, polyethylene, PVC, and rubber), hexachlorobenzene, chlordane, perchloroethylene bottoms, trichlorethane, chloroform, organic 


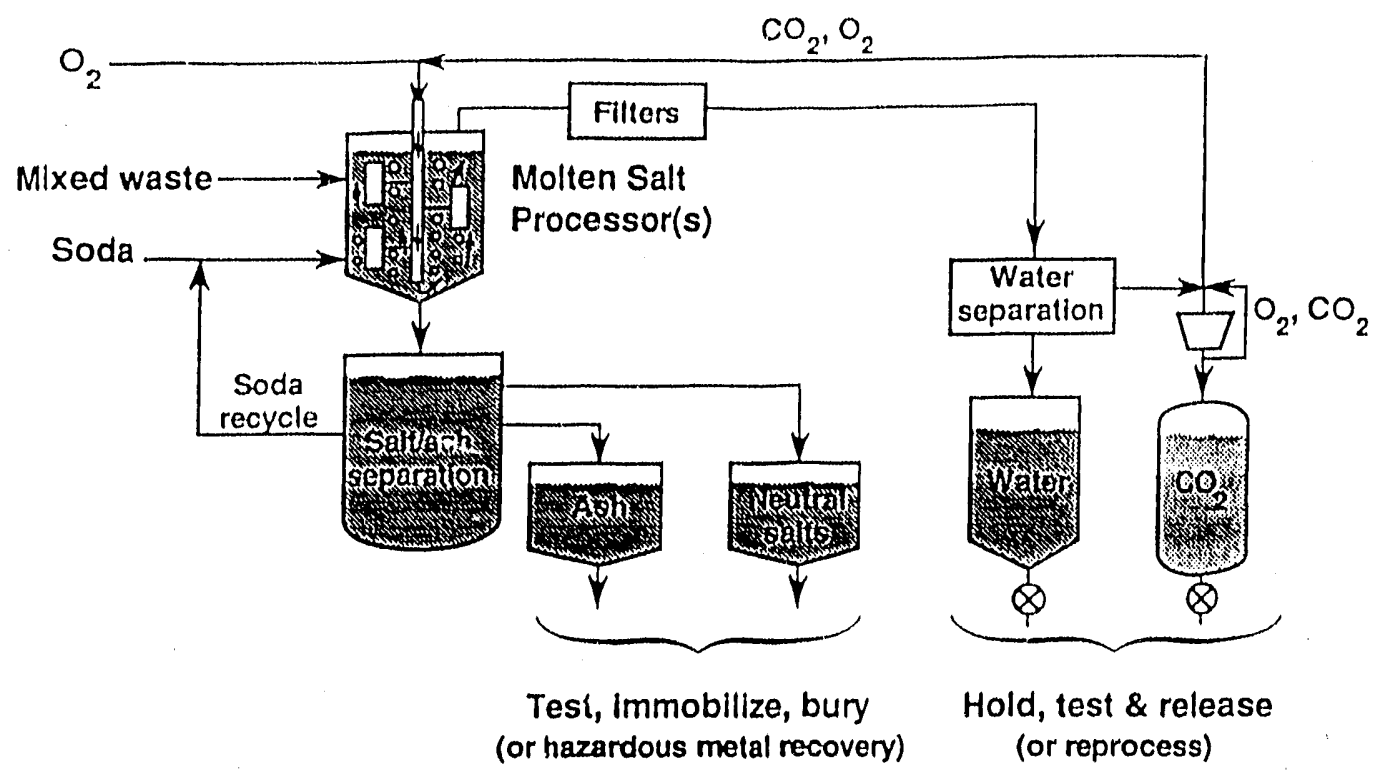

Figure 2-1. Overall process concept for molten salt processing of radioactive mixed waste with offgas condensation and salt recycling. ${ }^{4}$

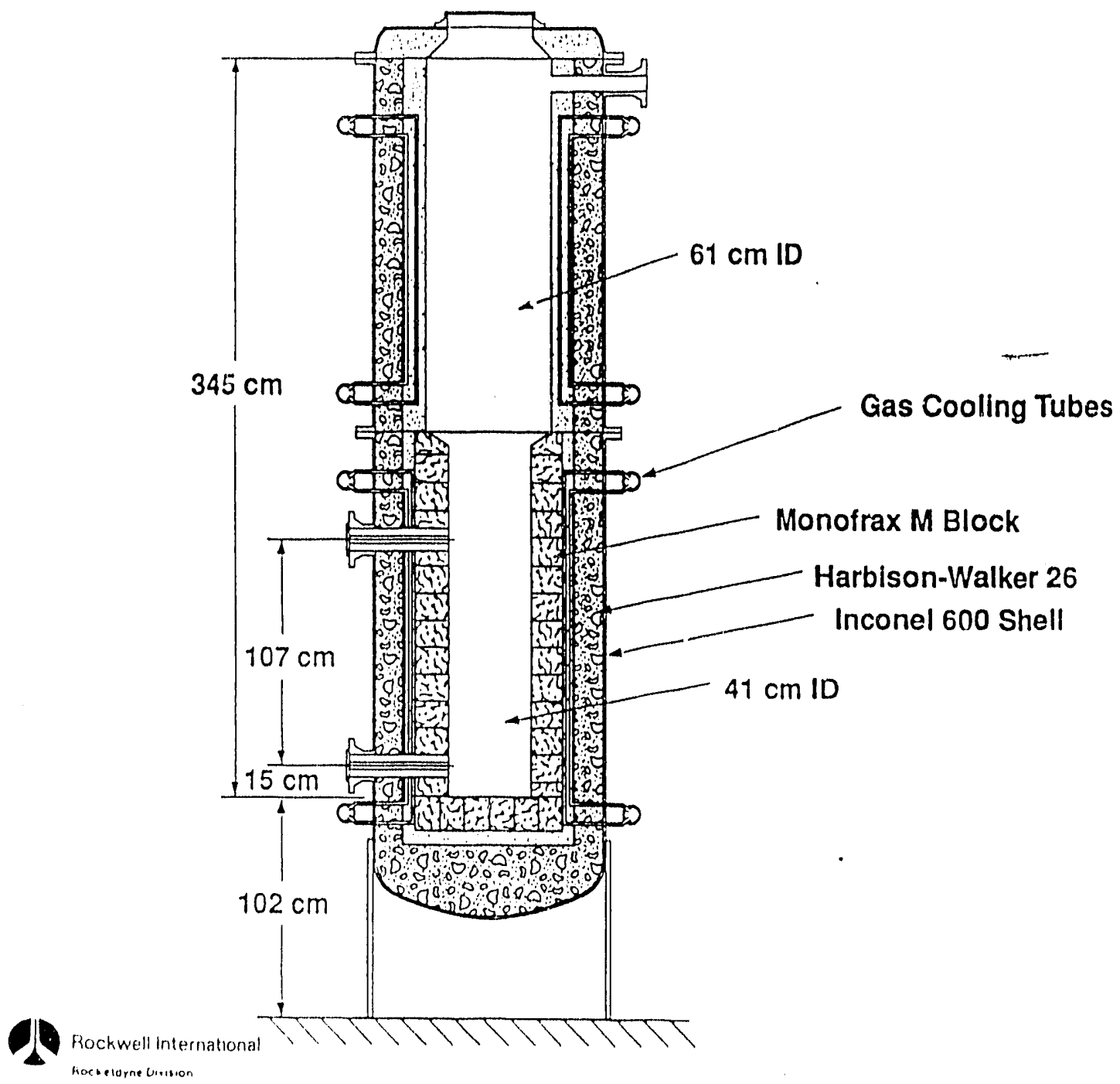

Figure 2-2. The Molten Salt Process Unit Rockwell International designed. ${ }^{4}$ 
fluorides, diphenylamine-HCL, monoethanolamine, pesticides, chemical warfare agents, tributylphosphate, ion exchange resins, silicon carbide, leaded gloves, and aqueous slurries. ${ }^{6}$

Destruction efficiencies for the pesticides were as high as $99.9998 \%$. Halogenated organics and chemical warfare agents were destroyed with efficiencies exceeding seven 9 s $(99.99999+\%)$.

Solid wastes must be sized (e.g., shredded, ground, or crushed) to allow pneumatic transportation into the processor and subsurface injection. The pilot-scale system $(250 \mathrm{lbs} / \mathrm{hr})$ requires sizing to $1 / 4$-in. Aqueous wastes must first be vaporized before injection below the surface of the molten salt. ${ }^{5}$

\subsubsection{Theory of Operation}

Figures 2-3 and 2-4 show the process flow diagram for the molten salt reactor. Figure 2-3 shows the waste and oxygen inputs, the molten salt processor, the offgas treatment and condensation system, and the recycle streams for offgas and salt. Figure 2-4 shows the unit operations for separation of the soda, salt, and ash discharged from the molten salt processor. This sequence of dissolvers, evaporators, and filters divides the molten salt stream into an ash-rich fraction, a salt-rich fraction, and a soda-rich fraction. The soda-rich fraction is recycled into the reactor. The other two streams are process outputs for disposal.

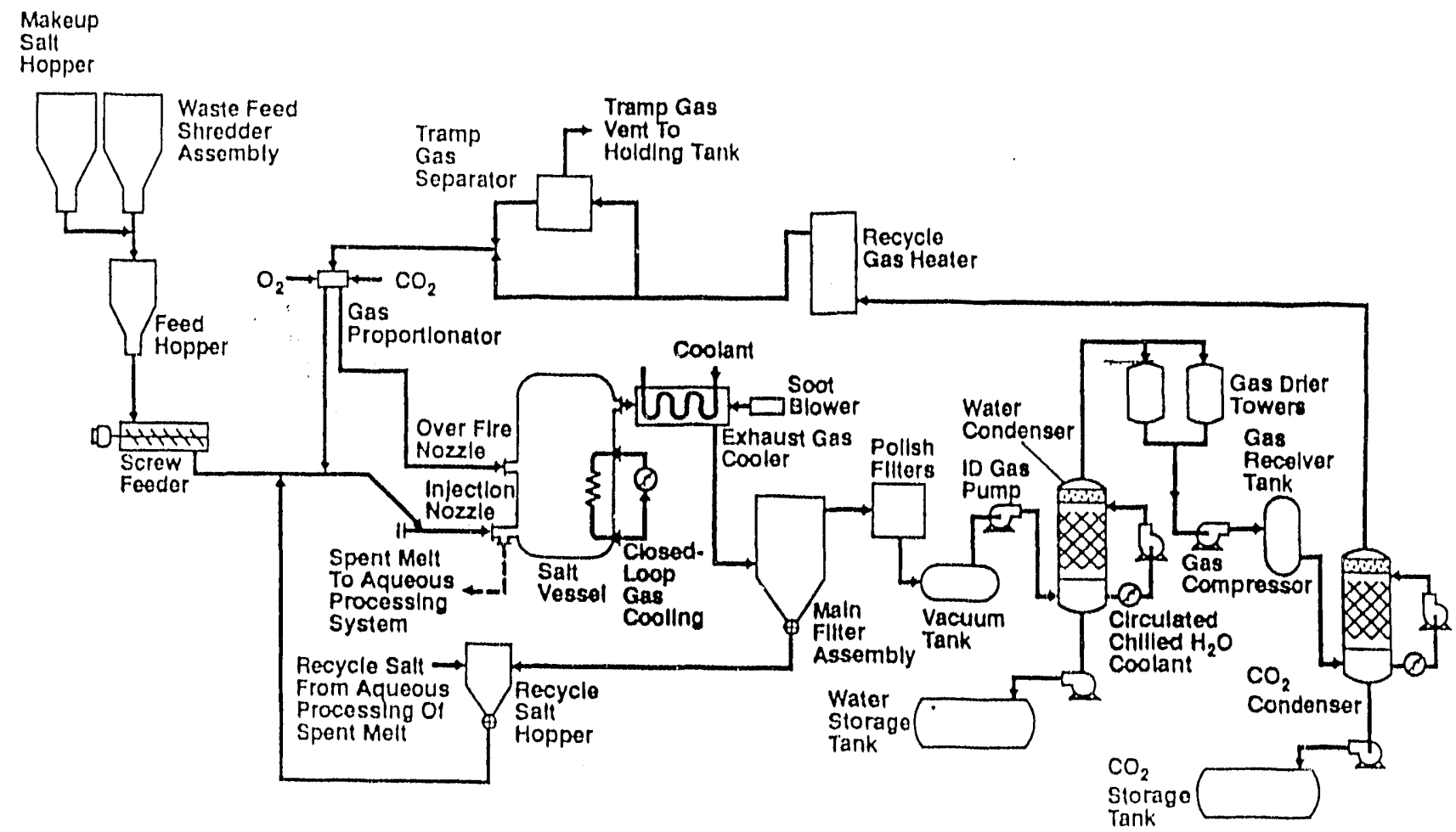

Rockwell international

Acchelopne tivisuan

Figure 2-3. Molten Salt Waste Treatment Process schematic showing Offgas Condensation System. ${ }^{4}$ 


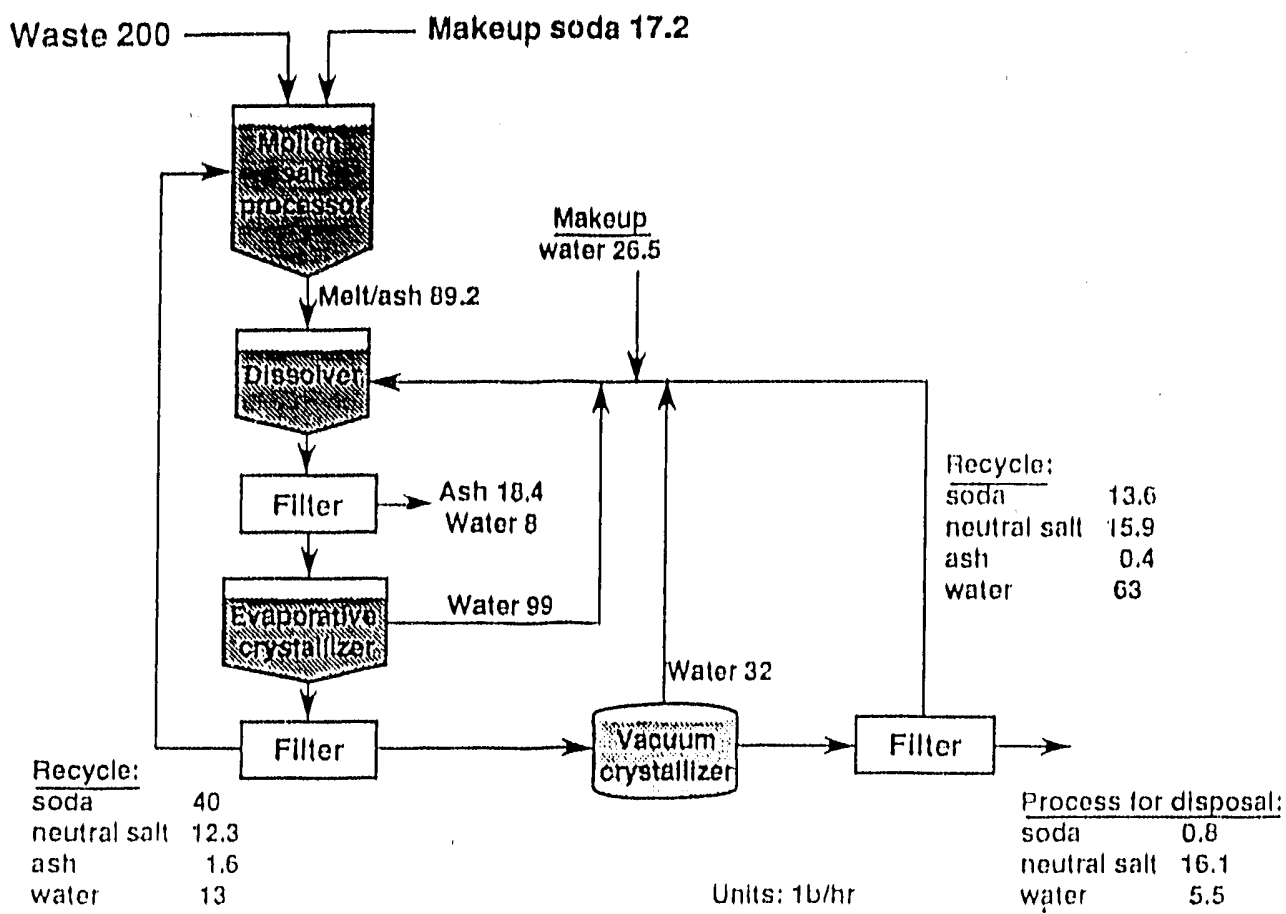

Figure 2-4. Process flow schematic for recycle of spent salt. ${ }^{4}$

Figure 2-5 shows a schematic of the molten salt process. This figure is a simplified diagram of the overall process, showing only the inputs, outputs, and primary recycle streams.

Referring to Figure 2-5, waste material is shredded, mixed with make-up salt and auxiliary fuel (c.g., liquid fuel oil), combined with an oxygen stream and injected into the molten salt reactor. The oxygen stream is a mixture of oxygen and carbon dioxide. This is substituted for air in order to minimize the nitrogen concentration in the offgas. The waste is shredded to a size smaller than 1/4-in. to allow the waste to be pneumatically transported into the reactor. To prevent shortcircuiting, the material must be injected approximately 12 -in. below the surface of the molten salt bed. The gases injected below the bed surface expand the bed. The operating bed height is about twice that of the quiescent bed, and therefore the injection is about 24-in. below the surface during operation. Oxygen reacts with the waste and auxiliary fuel (typically natural gas). The bed absorbs released heat that gas cooling circuits remove through the reactor walls. This cooling capacity limits the allowable energy release and thus limits the process capacity for combustible wastes. Injected gases and gases formed during the combustion process percolate up through the bed. The sodium carbonate bed absorbs the acid gases, resulting in a scrubbing of the offgas to form sodium chloride (salt). The offgas is cooled (via indirect heat exchange), filtered, and then sent to the gas condensation system.

Inert materials are removed from the reactor along with bed material. A three-step salt recovery process is used to treat this discharge stream. The process results in a water-washed ash, a soda-rich fraction for recycle to the reactor, and a chloride rich waste stream. 


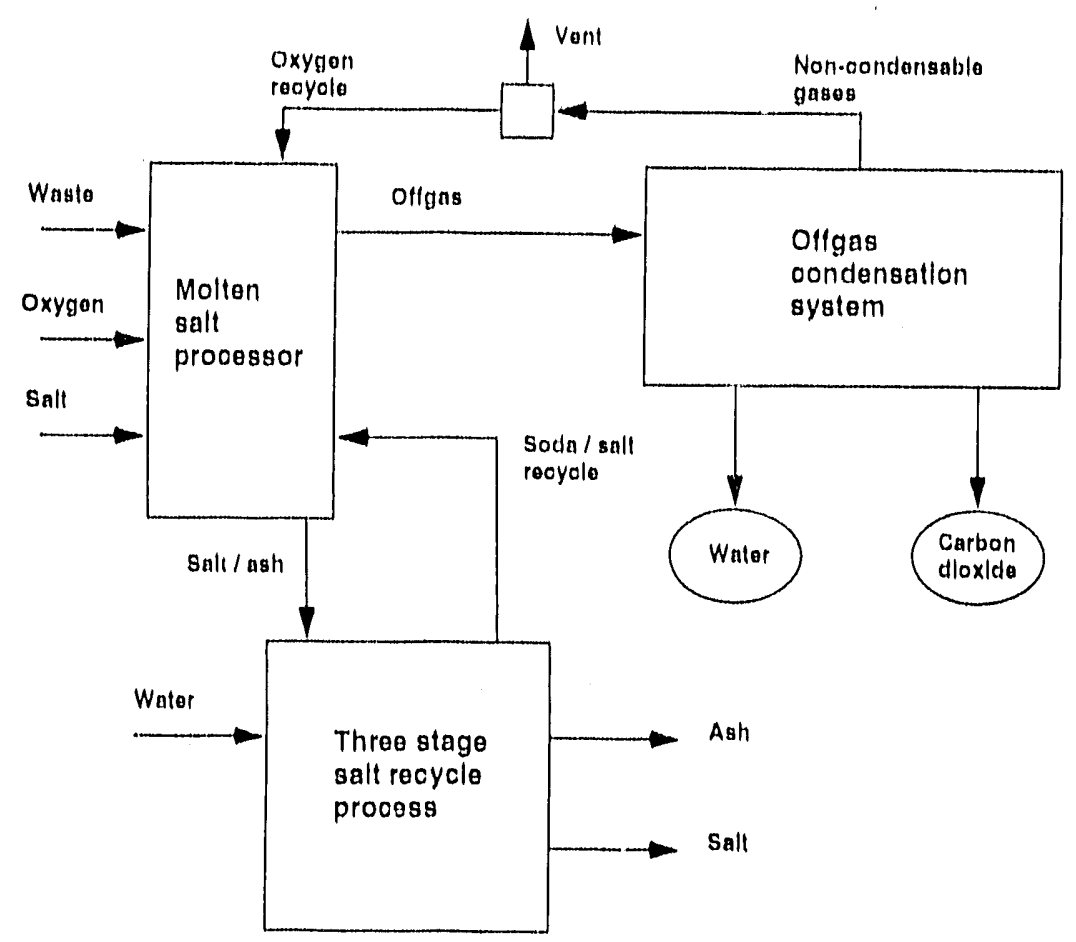

Figure 2-5. Simplified process schematic for Molten Salt Processor, Offgas Condensation System, and Salt Recycle System.

The molten salt combustion process operation is semicontinuous. The vessel is loaded with an initial molten salt charge and preheated to the desired operating temperature. A preheating is accomplished by electric heating coils surrounding the vessel. Waste and oxygen are introduced on a continuous basis. After the ash content of the molten bed reaches $15-30 \%$ or the chloride level rises to $90-95 \%$, the feed is stopped. The bed is drained and the reactor is recharged with carbonate bed material.

During waste processing, the offgas exits the molten salt reactor at 90()$^{\circ} \mathrm{C}$. An indirect heat exchanger (at the exit of the reactor) reduces the temperature to $2000^{\circ} \mathrm{C}$. The offigas passes through the main filter, which removes large particles (primarily salt) and returns them to the reactor. The offgas then passes through polishing filters (including HEPA filtration), which remove fine particulates. The gas is chilled after this filtration. Water in the offgas condenses and is removed as a liquid. The dewatered offigas passes through a gas drier (molecular sicves) to remove any remaining moisture. The dry offyas is compressed and further chilled to condense carbon dioxide. Gases remaining after removal of the carbon dioxide are returned to the reactor vessel. A portion of the recycle stream is vented to the atmosphere.

Ash is the primary waste stream. It contains a high percentage $(>9())$ of the inert material in the feed and ash liberated in the combustion process. Because the ash is separated from the molten salt in an aqueous dissolution process, the ash waste stream is in the form of a aqueous sludge with at least $30 \%$ water. This stream will contain a majority of the radioactive components in the feed.

The salt waste stream contains the salt, which is typically sodium chloride and generated during the treatment of chlorinated hydrocarbons. The composition of this stream is expected to be $72 \%$ 
salt, $3 \%$ soda, and $25 \%$ water. This stream may be radioactive. If the activity is very low, it may not require further treatment before disposal. The disposal of this stream is undetermined, both from a regulatory and a technical standpoint.

The polish filter waste stream consists of line particulate removed from the off'gas stream. It is expected to be lower in radioactivity than fly ash produced by conventional incineration. This expectation is based on the combined effects of a lower operating temperature and the unique salt bed scrubbing. This process results in a low mass of offgas particulate. Therefore this stream should be smaller than that produced by conventional incineration.

\subsubsection{Material and Energy Balances}

Figure 2-6 shows a mass flow diagram for the process of Figure 2-5. The primary inputs are waste, salt makeup ( $\sim 0.09 \mathrm{lb} \mathrm{NaCO}_{3} / \mathrm{lb}$ waste), and oxygen $\left(\sim 2 \mathrm{lb} \mathrm{O}_{2} / \mathrm{lb}\right.$ waste). The primary outputs are offgas $(\sim 3 \mathrm{lb} / \mathrm{lb}$ waste), filter residue, ash sludge $(\sim 0.1 \mathrm{lb} / \mathrm{lb}$ waste $)$, salt $(\sim 0.1 \mathrm{lb} / \mathrm{lb}$ waste $)$, liquid water $(\sim 0.7 \mathrm{lb} / \mathrm{lb}$ waste), liquid carbon dioxide $(\sim 1.7 \mathrm{lb} / \mathrm{lb}$ waste $)$, and vented gases $(\sim 0.06 \mathrm{lb} / \mathrm{lb}$ waste $)$. The gas recycle stream contains a significant quantity of uncondensed carbon dioxide. In the actual process this carbon dioxide is blended with the oxygen before introduction to the molten salt processor. This dilutes the oxygen stream to about 50\% oxygen and decreases the rate of heat released within the processor.

Figure 2.7 is a graphical representation of the energy flow that correspond to the mass flow of Figure 2-6. In a conventional incinerator, 80-90\% of the combustion energy exits the incinerator in the offgas. In this process, $76 \%$ of the combustion energy is removed in the primary vessel, only $21 \%$ exits with the offgas. This illustrates why the auxiliary cooling capacity limits the processes capacity for treating combustible waste.

\subsection{Technology Analysis}

\subsubsection{Advantages}

Molten salt processing has demonstrated capabilities for achieving the destruction and removal efficiencies required to meet current hazardous waste treatment standards. The molten salt bed traps halogens in the waste feed and eliminates the need for offgas treatment components normally required for removal of acid gases. ${ }^{7,8,9}$ Tests indicate that the molten salt bed will trap 95-99.9\% of the radionuclides in the feed. ${ }^{1,2,3,5}$ This will result in an offgas with lower activity than that produced by conventional incineration. In summary, the key advantages of the molten salt process are as follows:

- It achieves DREs that regulations require

- Halogens are scrubbed during the process

- Radionuclides are partitioned to salt bed. 


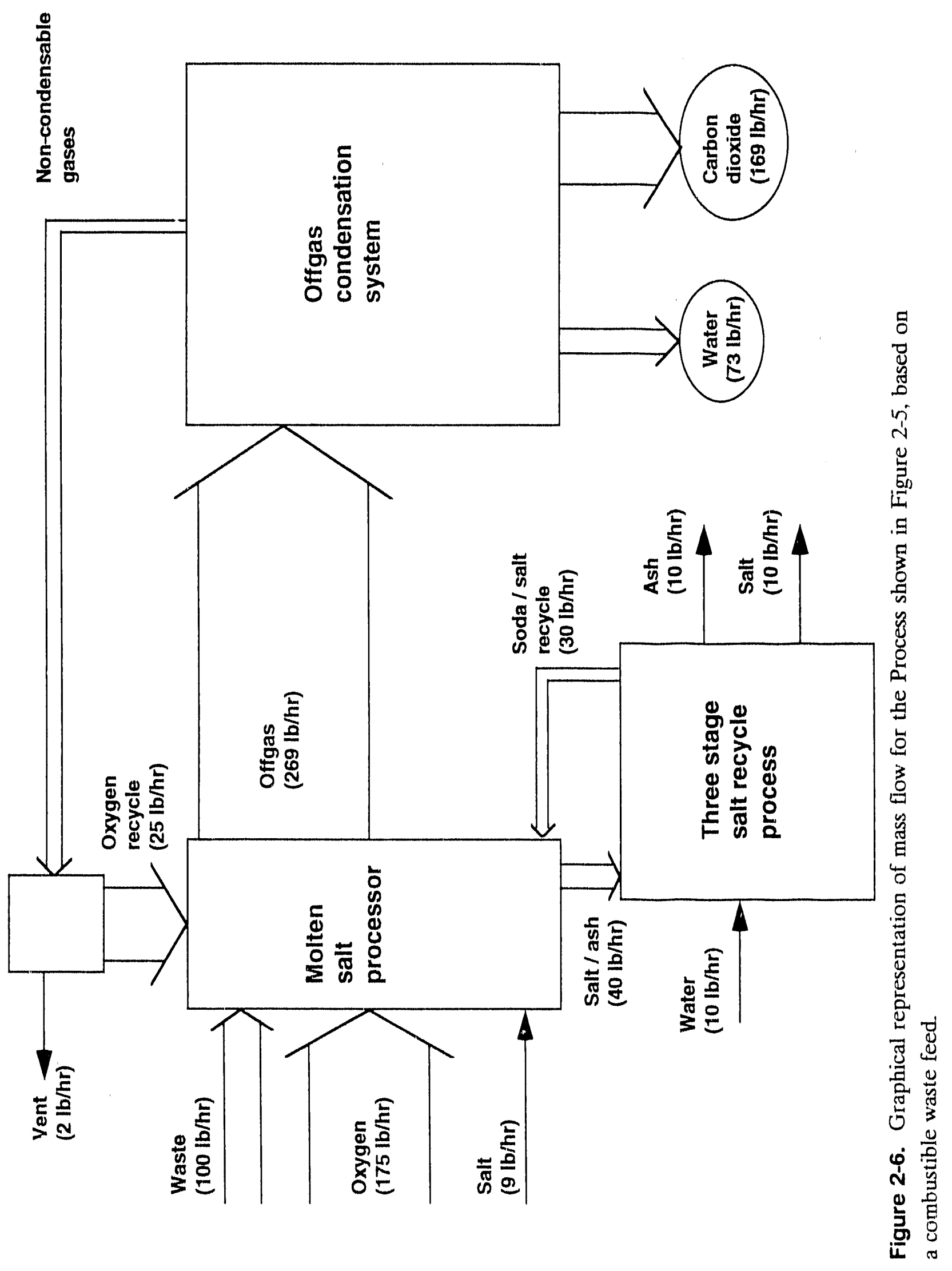




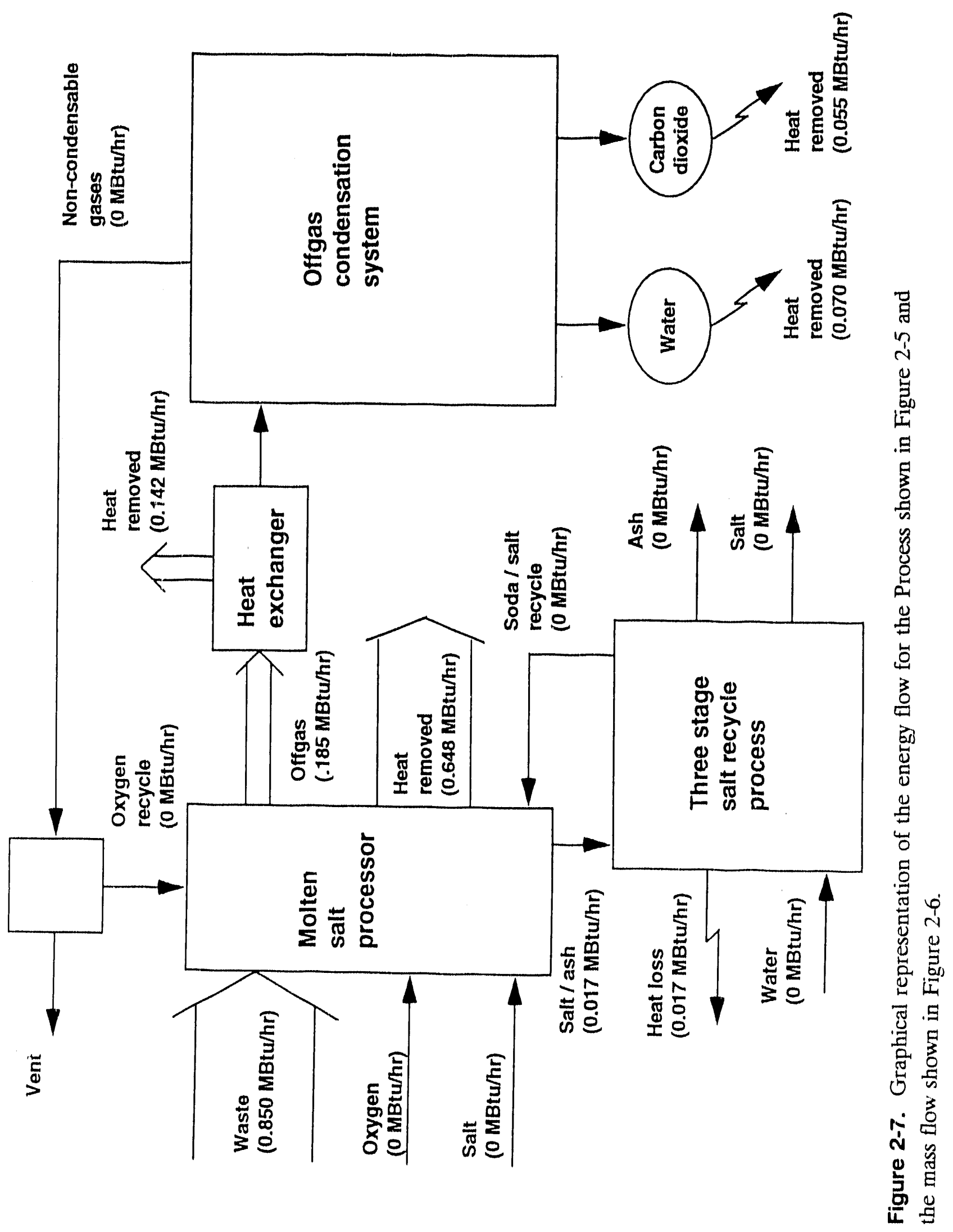


The concept of offgas condensation has advantages for treatment of hazardous and radioactive wastes. This concept allows for complete analysis and characterization of the offgas before it is released to the environment. This analysis can include procedures that require several hours to obtain results. Offgas that does not meet discharge specifications can be reprocessed in the molten salt unit (or treated by a separate process) before release to the environment. The key advantages of the offgas condensation process are as follows:

- The process allows for a complete analysis of offgas before it is released to the environment

- Offgas analysis is not limited to "online" diagnostics

- Offgas that does not meet specifications can be reprocessed before release.

\subsubsection{Disadvantages}

There are some disadvantages and limitations to the molten salt process. The feed material must be pretreated to reduce its size to $<1 / 4$-in. High ash content feed materials (especially those high in alumina) require frequent changes of the bed material and this adds to the process cost. The process involves high temperature operation with corrosive salts. This increases the cost for materials of construction and may increase maintenance costs. Recycle of the bed material or separation of the soda, salt, and ash is a liquid phase process. This increases safety concerns when processing plutonium contaminated material. The by-product streams from this process are filter cakes from an aqueous process. These sludges will most likely require further treatment before disposal. In summary, the key disadvantages of the molten salt process are as follows:

- Waste feed must be pretreated, or shredded to 1/4-in.

- The process is incfficient for treating waste materials with a high ash (inert) content

- The high-temperature process with a corrosive environment may result in materials of construction problems

- By-product streams are filter cakes from an aqueous process (i.c., sludges)

- The recycling of salt (separation of ash) is a liquid phase process.

There are also some disadvantages and concerns about offgas condensation. This is obviously more expensive than the gas phase, "onee-through" offgas treatment and release. As with other thermal treatment processes, the offgas system capacity limits the system peak capacity. What treatment will be required if the liquid water or liquid carbon dioxide does not meet the release criteria is not clear. This process involves several unit operations that may be difficult to control when they are driven by a fluctuating waste treatment process. The key disadvantages to the eoncept of offgas condensation are as follows: 
- Capital and operating expenses are higher than for conventional offigas treatment processes.

- The increased number of unit operations increases the complexity of the waste treatment operation.

- Fluctuations normally associated with waste treatment offgas flows and compositions may impair the operation of the offgas condensation system.

\subsubsection{State of Development}

Rockwell researchers have been developing this technology since 1969. Bench and Pilot-Scale tests have been performed on a wide range of waste materials. The molten salt processor with salt recovery has been operated continuously for combustion of coal.

Long term, continuous opcration of feeding the actual waste has not been demonstrated.

\subsubsection{Research, Development, or Demonstration Needs}

The molten salt processor needs to be demonstrated on an actual waste stream for an extended period of time. Operational concerns to be evaluated include the following: corrosion in the vessel, corrosion in the offgas treatment system, throughput versus waste heating value, annual system capacity allowing for semicontinuous operation, and disposal status of by-product streams. The following paragraphs identify some questions that should be addressed in a research and development or demonstration program.

Several questions revolve around the actual unit capacity: What is the allowable processing rate for specific wastes and a given process? What is the annual processing capacity after accounting for loading, preheating, waste throughput, ash/salt discharge, and preparation for the next treatment campaign? How does the peak system capacity compare with the average capacity for a given waste stream?

Other questions involve materials of construction and how variations in the feed impact them. The refractory in the reactor is designed for a specific molten salt composition. Will variations in the waste feed affect the refractories, erosion ratc?

The offgas condensation system still is only in the concept stage. There is a variety of questions that can be addressed relative to the operation of this system: Is the heat exchanger at the exit of the molten salt processor subject to corrosion though this heat exchanger has a soot blower to remove deposits? If this unit were operated with real waste, how often would this unit require cleaning? Is this likely to be a major maintenance item?

An important concern in the design of the offgas condensation system is the system response to a varying load. Waste feed materials have nonuniform composition. This leads to fluctuations in the combustion process, and this can dramatically affect downstream equipment. The ability of the offgas condensation system to respond to a varying load may have a dramatic impact on the true system capacity. 


\subsection{Applicability to INEL Buried Waste}

The molten salt processor is best suited for the treatment of the combustible waste obtained from sorting the buried waste. However, this stream will require pretreatment to reduce the size of the feed material.

The molten salt processor also may be useful in treating some of the INEL sludge streams. The aqueous sludges can be treated only by mixing with an organic fuel and vaporization before injection is preferred. Because the aqueous sludges are primarily inert, they are not a good candidate for the molten salt process. The organic sludges can be readily treated, however, the high levels of inerts may detract from system performance. Evaporation salts with a high concentration of nitrates wiil result in the formation of significant quantities of $\mathrm{NO}_{\mathrm{x}}$. These salts should probably not be treated in a thermal process.

The inert waste stream should not be treated in the molien salt processor. This technology is not designed for high ash loadings. This technology does not provide any means of stabilizing hazardous metals ano can not melt or dissolve solid metal objects.

The mixed waste stream will have a high inert component and should not be considered for the molten salt processor.

\subsection{References}

1. L. F. Grantham, D. E. McKenzic, W. L. Richards, and R. D. Oldenkamp, "Molten Salt Combustion of Radioactive Wastes," CONF-760822, 1, 9 (1977).

2. D. E. McKenzie, L. F. Grantham, and R. P. Paulson, "Volume Peduction of Radioactive $\beta$ $\gamma$ and TRU Waste by Moiten Salt Combustion," Symposium on Management of Low-Level Radioactive Waste, Atlanta, Georgia (1977).

3. L. F. Grantham, D. E. McKenzic, R. D. Oldenkamp, and W. L. Richards, "Disposal of Transuranic Solid Waste Using Atomics International's Molten Salt Combustion Process, II," AI-ERDA-1369, March 15, 1976.

4. John F. Cooper, et al., "Molten Salt Processing of Mixed Wastes with Offgas Condensation," 1991 Incineration Conference, Knoxville, Tennessee, May 1.3-17, 1991, Proceedings, pp. 31-38.

5. A. E. Stewart, S. J. Yosim, A. J. Darnell, and R. L. Gay, Preconceptual Design of a Closed Molten Salt Destruction System for Mixed Waste, Energy Technology Engineering Center, Rockwell International, MSDS-XY-(00)1, April 11, 1991.

6. J. G. Johanson, S. J. Yosim, L. G. Kellogg, and S. Sudar, "Elimination of Hazardous Wastes by the Molten Salt Destruction Process," Paper presented to the American Society of Testing Materials Committee D-27, March 22-4, 1982. 
7. A. J. Darnell and R. L. Gay, Design Parameters for Aqueous Processing of Melts from Molten Salt Destruction of Mixed Wastes, Energy Technology Engineering Center, Rockwell International, MSDS-XY-00C2, April 11, 1991.

8. Marc Breton, et al., Treatment Technologies for Solvent Containing Wastes, NTIS Report No. PB87-129821, October 1986, pp. 11-20 to 11-28.

9. Harry Freeman, Molten Salt Destruction Process: An Evaluation, Report on Work Supported by EPA/California Cooperative Agreement - EPA \#R808908, 1980. 


\section{MICROWAVE MELTER}

\subsection{Technology Background}

Microwave technology has been used in the food and chemical industries since the early 1970)s. The majority of the industrial applications have been focused on drying and vulcanizing rubber. ${ }^{1}$ High temperature technology was developed in Japan for converting plutonium nitrate recovered from spent fuel reprocessing to plutonium oxide for nuclear fuel production and for solidifying waste incinerator ash. ${ }^{2}$ During the late 1970 s, researchers at INEL performed laboratory scale vitrification tests using microwave energy. High-level wastes were mixed with additives, placed in a ceramic crucible, and heated in a microwave cavity. The resulting glass was poured into a metal storage container and allowed to cool. ${ }^{3}$

Researchers at the DOE's Rocky Flats Plant (RFP) in Golden, Colorado, are developing a microwave system for the drying, solidification, and vitrification of metal hydroxide sludges produced as a secondary waste from the treatment of aqueous wastes containing heavy metals. ${ }^{4}$ This work was initiated in the late 1980)s while Rockwell International managed RFP for DOE. This work is now being conducted by EG\&G Rocky Flats, DOE's management and opcrations contractor at RFP.

The microwave system consists of two units. The first unit is a belt driven microwave dryer that is available from commercial vendors. The RFP drying tests were conducted at Cober Electronics, Inc., Stamford, Connecticut. The second unit is a microwave melter. The melter consists of an $8 \mathrm{~L}$ stainless steel container lined with $12 \mathrm{~mm}$ thick Fiberfrax insulation. An initial charge of $2.0 \mathrm{~kg}$ of dried sludge was placed in the container and heated to a temperature between 1000 and $1300^{\circ} \mathrm{C}$. After establishing a melt, additional sludge was added at a rate of $3.0 \mathrm{~kg} / \mathrm{hr}$. Energy consumption averaged $2.2 \mathrm{~kW} . \mathrm{hr} / \mathrm{kg}$ of dry sludge.

\subsection{Process Description}

\subsubsection{Current Waste Applications}

At RFP, this system has been tested only for treatment of metal hydroxide sludges. Aqueous wastes generated by plutonium recovery operations are treated in a hydroxide precipitation process. This process produces an aqueous slurry of heavy metal hydroxides. The metal hydroxides are removed from the water with a rotary drum vacuum filter. This filter is precoated with a diatomaceous earth filter medium. Thus filter cake, or sludge, produced by cleaning the aqueous waste, consists of heavy metal hydroxides, diatomaceous earth, and water. Two microwave process have been tested at RFP. The first process consists of using microwave energy to dry sludges in a conveyor type dryer. The second process consists of using microwave energy to melt sludge in steel containers. The drying was conducted at rates varying from 6 to $12 \mathrm{~kg} / \mathrm{hr}$, while the melting was conducted at rates ranging from 2 to $3 \mathrm{~kg} / \mathrm{hr}$.

In Japan, similar technology is used in the Plutonium Wastes Treatment Facility (PWTF) at Tokai Works, of the Power Reactor and Nuclear Fuels Development Corporation (PNC). ${ }^{5}$ At this facility, in-can microwave melting is used to solidify plutonium contaminated incinerator ash. 
Recently this technology has been extended to square crucibles for efficient use of storage space. ${ }^{6,7}$ These tests used square crucibles made of carbon steel or stainless steel. The crucibles were $228-\mathrm{mm}^{2} \times 800-\mathrm{mm}$ deep and had a capacity of $42 \mathrm{~L}$. The tests were conducted in a microwave system with an output power of $25 \mathrm{~kW}$. Incinerator ash was processed at a rate of $15 \mathrm{~kg} / \mathrm{hr}$ (energy consumption of $1.66 \mathrm{~kW} . \mathrm{hr} / \mathrm{kg}$ ).

Studies in Japan also have examined the use of this technology for the solidification of concrete lumps, asbestos fiber, glass fiber, pearlite, rock wool, dried residues of liquid waste $\left(\mathrm{Na}_{2} \mathrm{~B}_{4} \mathrm{O}_{7}, \mathrm{Na}_{2} \mathrm{SO}_{4}, \mathrm{NaNO}_{3}\right.$ ), residues of acid digestion, soil and sand, and metal pieces (nails and bolts). ${ }^{6}$

\subsubsection{Theory of Operation}

Microwave energy heats materials through three primary mechanisms discussed by the following. Type I heating is characterized as vigorous vibration of a dipole molecule. This vibration is caused by oscillation of the electromagnetic field. The vibration causes frictional heat to build up between the molecules, which elevates the temperature of the material. Although metal oxides (e.g., $\mathrm{MgO}, \mathrm{Al}_{2} \mathrm{O}_{3}, \mathrm{CaO}$, and $\mathrm{SiO}_{2}$ ) are normally electrically neutral, when placed in a electromagnetic field they become dipolar. ${ }^{4}$

Type II heating involves substances that are magnetic in nature and couple with the magnetic component of the microwave field. The oscillation of the magnetic component of the field results in hysteresis loss within the material, which generates heat. ${ }^{4}$

Type III heating takes place when an electrically conductive material, such as carbon black, is a component of the material being heated. A current is generated throughout the material by the electric component of the microwave field. The material is heated by the current flow through the electrical resistance. ${ }^{4}$

For treatment of a plutonium contaminated material, all of the drying and melting operations are conducted within a sealed "glovebox." The microwave power supply and controls are located outside of the glovebox. Microwave energy is coupled to the process through a quartz window. This operation is essentially the same as a microwave oven used for residential cooking. The differences are in power $(60 \mathrm{~kW}$ vs. $0.6 \mathrm{~kW})$, size $\left(60 \mathrm{ft}^{3} \mathrm{vs} .1 \mathrm{ft}^{3}\right)$, and placement of the microwave power source. In a residential microwave the power source (magnetron), waveguide, and cavity (oven) are contained in a single cabinet. In a commercial system the power source (magnetron) is located several feet away from the cavity. A waveguide, which is typically a rectangular metal tube, connects the power supply to the cavity. The cavity can be very large, units $10 \mathrm{ft}$ in dia. have been constructed. The cavity can receive power from several power sources.

Figure 3-1 shows the process flow diagram for a microwave drying and melting system. The waste (metal hydroxide sludge) contains $65 \%$ water, $23 \%$ diatomaceous earth, and $12 \%$ metal hydroxides. This process is based on the results of tests by researchers at RFP. ${ }^{4}$ The flow diagram of Figure 3-1 and the following description are an extrapolation of their tests results and their suggestions for a full scale process. The sludge is evenly distributed over a conveyor belt with a depth of $2.3 \mathrm{in}$. The material is conveyed through a microwave cavity at a rate of $30 \mathrm{~cm} / \mathrm{min}$. The 


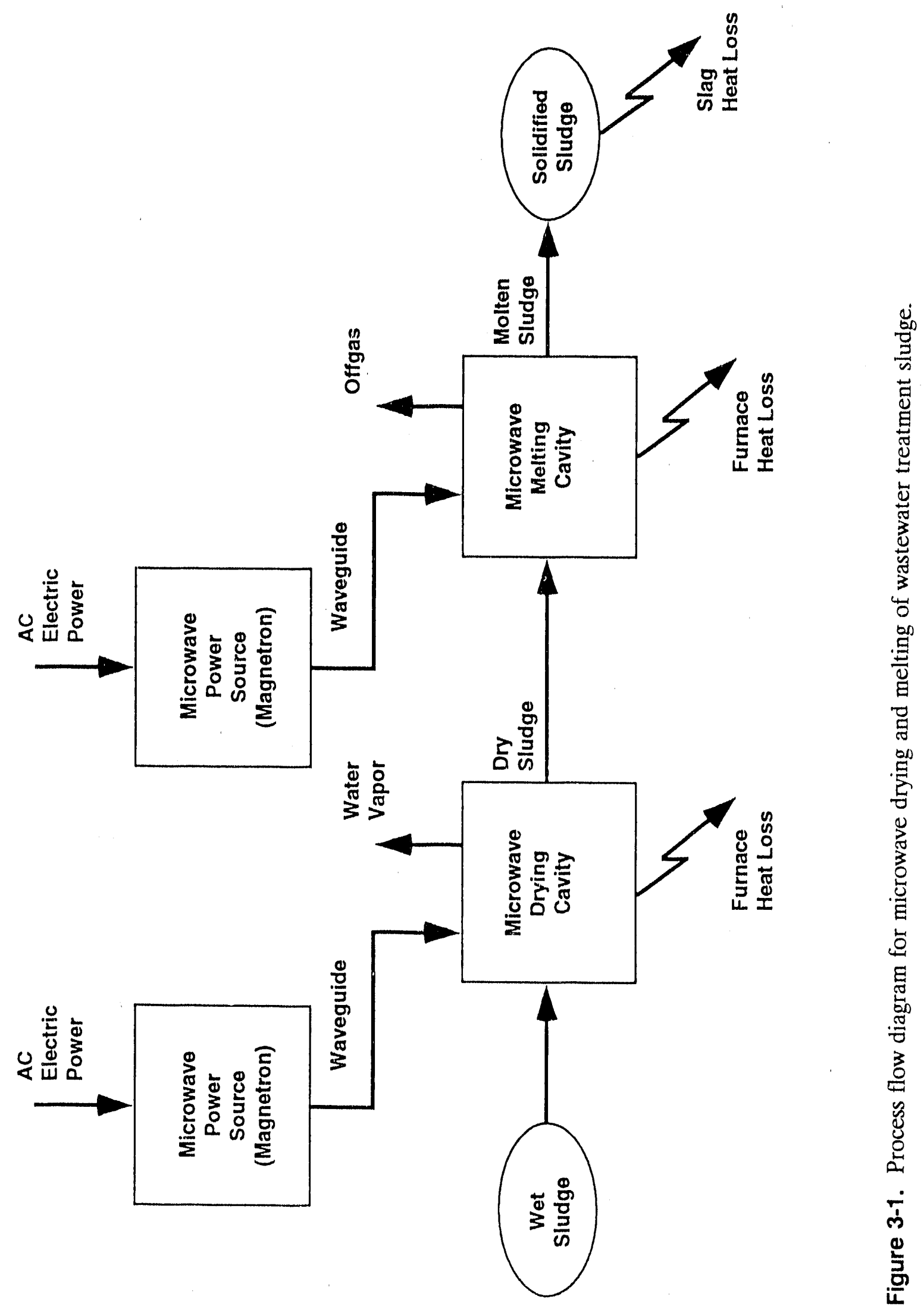


microwave cavity is $3-6 \mathrm{ft}$ long and has a power supply capable of delivering $60 \mathrm{~kW}$ to the cavity. After exiting the cavity, the dried sludge is mechanically transported to the microwave melting system.

The microwave melting system uses the same type of power supply and waveguide as the drying operation. The cavity is different because the geometries are different. The power density may be higher, and the materials of construction must withstand higher temperature operation.

The full scale system under development at RFP is based on in-drum melting. A $30 \mathrm{gal}$. thermally insulated metal drum is placed inside the microwave melter cavity. A small quantity $(\sim 10 \mathrm{~kg})$ of dry sludge is placed in the drum and the microwave power is turned on. After a melt is established and the system is stabilized at the desired operating temperature, material is added continuously at a rate of $30 \mathrm{~kg} / \mathrm{hr}$. After feeding approximately $200 \mathrm{~kg}$, the feed is discontinued. Microwave power is maintained while the molten sludge releases trapped gases, which are removed by the "glovebox" exhaust system. Finally, the drum is removed from the microwave cavity and allowed to cool.

Operating temperature is limited by the materials of construction of the crucible and insulation. A metal crucible limits the practical operation temperature to $1350^{\circ} \mathrm{C}$. Ceramic crucibles allow temperalures in the $1600-1700^{\circ} \mathrm{C}$ range. To use in-drum melting (with operating temperatures below $1350^{\circ} \mathrm{C}$ ), it is necessary to add fluxes to lower the melt temperature of the feed material.

\subsubsection{Material and Energy Balances}

Figure 3-2 shows the material balances for a theoretical microwave drying and melting process. Sludge enters the dryer at a rate of $100 \mathrm{~kg} / \mathrm{hr}$ and contains $65 \%$ moisture. The dried sludge exits at a rate of $35 \mathrm{~kg} / \mathrm{hr}$ with a very low moisture content $(<1 \%)$. The offgas stream exiting the dryer contains $65 \mathrm{~kg} / \mathrm{hr}$ of water vapor along with any volatile contaminants in the sludge.

The dried sludge is then transported to the microwave melting system. The sludge is continuously fed to a crucible in the melter. Microwave energy melts the sludge and produces a molten mass. After the crucible is filled, the crucible and molten sludge are removed and allowed to cool. Gases evolve during the melting operation, and consist of any remaining moisture, volatile organics, and gases produced by the decomposition of inorganic materials. For example, nitrate saltswill release nitrogen oxide gases, carbonates will release carbon dioxide, and hydroxides will release water vapor.

Figure 3-3 shows an energy balance corresponding to the mass balance of Figure 3-2.

\subsection{Technology Analysis}

\subsubsection{Advantages}

Drying - Microwave technology provides a highly efficient means of drying solids. Drying efficiencies are in the range of $65-97 \%$, a common efficiency is $80 \%$. Because the magnetron typically operates at an efficiency of $80 \%$, the overall efficiency is on the order of $64 \%$. In this case drying efficiency refers to the theoretical energy required to volatilize all of the materials water and heat the material 


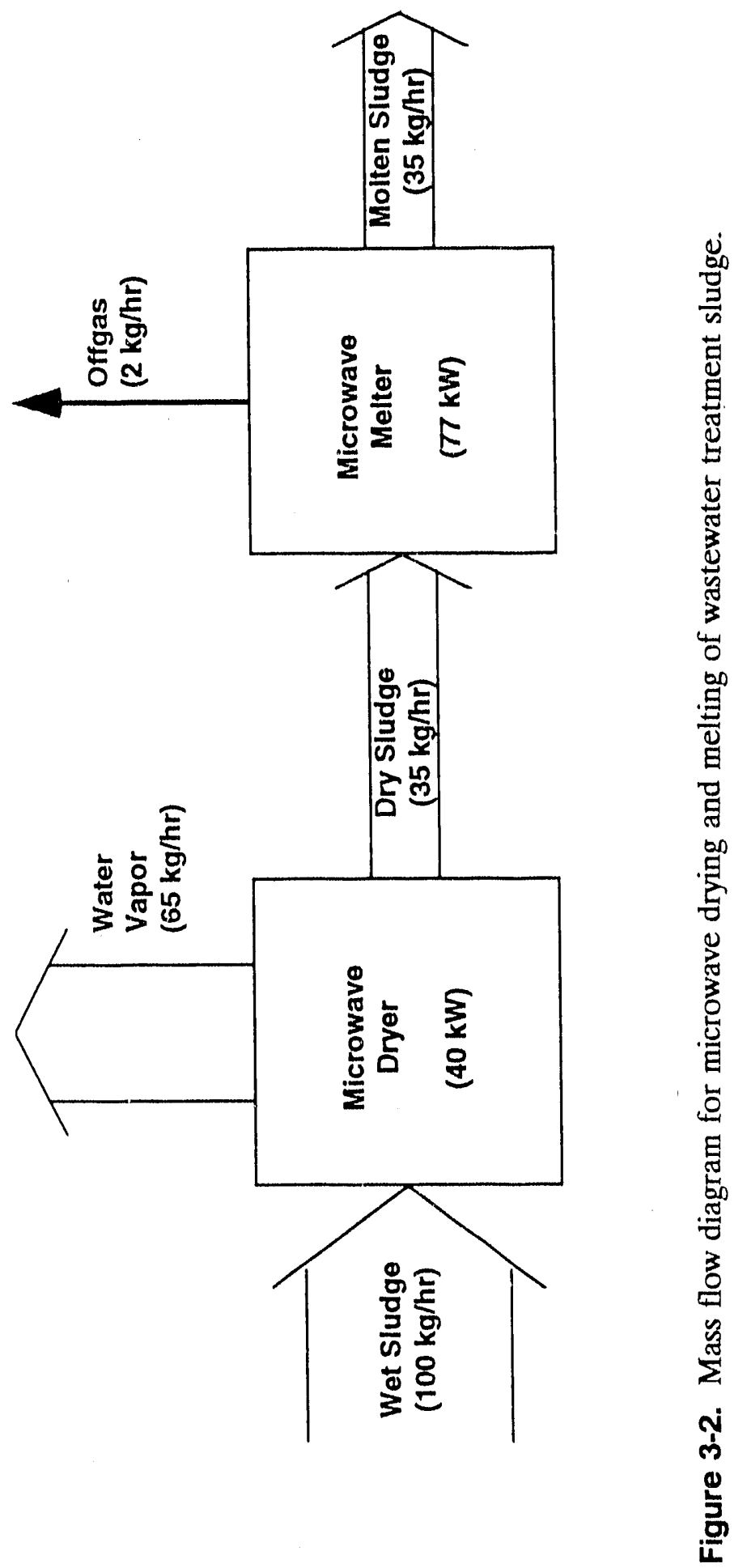




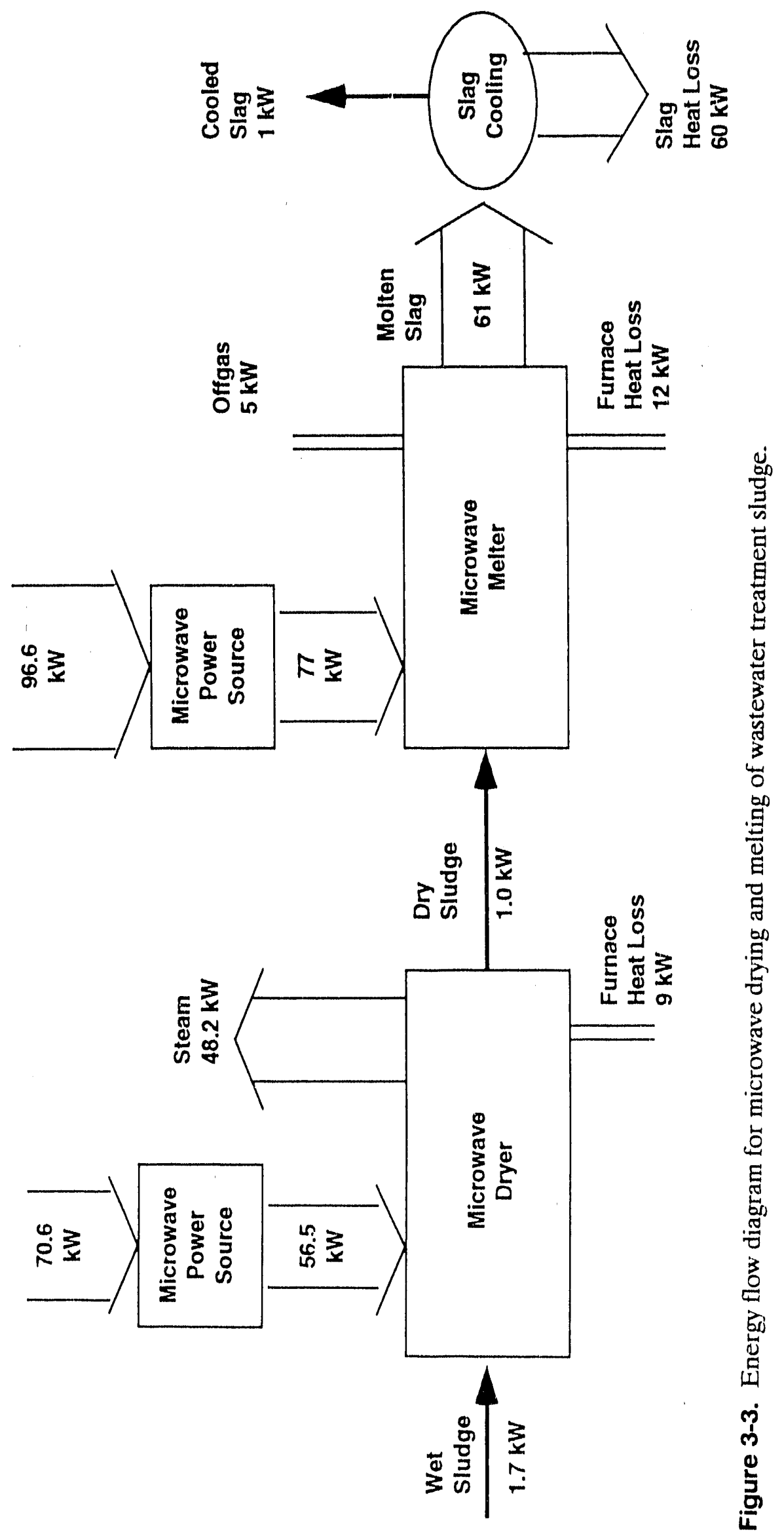


to $100^{\circ} \mathrm{C}$, divided by the total electrical energy used. Microwave energy couples directly to the material and heating occurs throughout the material. The only by-product associated with the process is the gas (primarily water vapor) and the material released during the drying process.

Melting - Microwave technology provides an efficient method of melting a uniform solid material. Power requirements are similar to those reported for other melting technologies $(\sim 1 \mathrm{~kW}-\mathrm{hr} / \mathrm{lb})$. Microwave systems can be completely sealed to provide contamination control for processing of radioactive materials. Microwave systems can be used for "in drum melting" which minimizes material handling. The final waste container is used as the crucible for the melting process.

\subsubsection{Disadvantages}

Drying - The material to be dried must be evenly distributed over a flat surface (typically a conveyor belt), with a depth of 1-3 in. Nonuniform feed materials and large objects will impair the operation of the process. Microwave technology is an expensive drying process because of the high capital costs and the use of electrical energy instead of fossil fucl.

Melting - Process throughput is limited. The process is operated in a batch mode and waste is fed continuously for brief time intervals. The entire crucible and melt are removed after the crucible is full. Batch sizes are on the order of one 55-gal drum and throughput per unit is limited to about $25 \mathrm{~kg} / \mathrm{hr}$.

Larger full scale processes may be feasible (up to several hundred $\mathrm{kW}$ ), however development is focused on in-drum molting.

\subsubsection{State of Development}

Drying - Microwave drying is a commercially available technology. There are several, about four U.S. firms that sell these systems. Most systems that are sold are custom designed and built for a specific application. Microwave power supply units are available in modules up to $60 \mathrm{~kW}$ in size. These modules can be connected to deliver several hundred $\mathrm{kW}$ of power to a single microwave cavity. The power density in any given cavity is limited to about $1 \mathrm{~kW} / \mathrm{ft}^{3, a}$

Melting - Microwave technology for melting is not as well developed. The equipment is essentially the same, however there are more operational problems. These problems are primarily associated with the higher operational temperatures and higher power densities necessary for melting processes. These problems include melting the containment vessel, electric arcing, which can lead to power supply damage, and nonuniform heating.

Offgas released by the melting of sludges has not been monitored or analyzed. The offgas generated from melting of radioactive waste will certainly require treatment. The type of treatment will depend on the composition of the offgas.

a. Private communication with M.R. Martin, Coher Electronics, Stanford, Connecticut, September 18, 1991. 


\subsubsection{Research, Development, or Demonstration Needs}

The process is operated in a semibatch mode. To determine the operating capacity, examining the time required to treat one drum is necessary. This will include setup of the drum, initial charging, treatment of the initial charge, temperature stabilization, treatment during drum filling, post treatment of the drum, and removal of the drum. An understanding of the actual steps and required times is required to evaluate the actual process throughput.

Melting of sludges will generate an offgas that will require further treatment. The quantity and composition of this offgas should be determined in order to identify the requirements of the offgas treatment system.

\subsection{Applicability to INEL Burled Waste}

This technology is not applicable to the combustible waste stream. The equipment has been developed only for the drying and melting of inert materials.

This technology is applicable to the aqueous based sludges. The sludges in the INEL buried waste originated at RFP and the development work at RFP has focused on this waste stream. It may be possible to treat the organic based sludges. Treatment of these sludges will result in a very different offgas, which will require further treatment, (e.g., combustion followed by air pollution control equipment).

The inert waste stream can be treated by this technology. If it has a low moisture content, the drying step may not be necessary. Some pretreatment will be required, but the technology may handle large (up to 6 in.) solids. The effect of large metal objects is not known. Metals will not be melted in the low temperature $\left(1300^{\circ} \mathrm{C}\right)$ process currently under development.

The most important question relative to the processing of INEL buried waste is the processing capacity. The planned process unit Rockwell International discussed has a power level of $50 \mathrm{~kW}$ and could potentially treat $10-25 \mathrm{~kg} / \mathrm{hr}$. This corresponds to a maximum treatment capacity of $150,(0)$ ) $\mathrm{kg}$ of inert material/yr/melter. Comparing this with INEL Buried Waste needs for inert material treatment capacity of $68,000,000 \mathrm{~kg}$ over 10 years, indicates that 45 melters would be required.

\subsection{References}

1. B. Krieger and R. D. Allen, "Improvement in Microwave Technology," 118th Rubber Division Meeting, American Chemical Society, Detroit, MI, October 1980.

2. H. Wshima, N. Tsuji, and H. Sato, Continuous Denitration Test Equipment Using Microwave Heating, RFP-TRANS-462, Translated from Toshiba Review, 39 (7), 611-614, 1984.

3. S. J. Pricbe, T. C. Piper, and J. R. Berreth, Application of Microwave Energy to PostCalcination Treatment of High-Level Nuclear Wastes, ICP-1183, Allied Chemical Corporation, Idaho National Engineering Laboratory, Idaho Falls, Idaho, February 1979. 
4. R. D. Petersen, A. J. Johnson, and S. D. Swanson, Application of Microwave Energy for InDrum Solidification of Simulated Precipitation Sludge, RFP-4248, UC-70) Nuclear Waste Management, DOE/TIC-45(1) (Rev.73), August 17, 1987.

5. Y. Ogata, J. Ohuchi, E. Inada, and N. Tsunoda, "Processing of Plutonium Contaminated Waste at PWTF," Management of Low and Intermediate Level Radioactive Wastes, IAEA-SM303/24, (1988).

6. Y. Tejika, F. Komatsu, T. Masaki, N. Yoshida, I. Fukai, "Three Dimensional Analysis of a Microwave Heating Furnace System," Journal of Microwave Power (Canada), Vol. 22:2, 1987, pp. 107-114.

7. Y. Tejika, F. Komatsu, T. Masaki, N. Yoshida, and I. Fukal, "Three-Dimensional Analysis of" Microwave Heating System with Square-Type Furnace, "IEEE Transaction on Nuclear Science, Vol. NS-34, 4, August 1987. 


\section{AUSMELT LANCE}

\subsection{Development History}

Ausmelt Pty., Lid., Victoria, Australia was formed in 1981 to promote commercialization of a new technology for high efficiericy smelting of a wide varicty of materials. 'This technology, named SIROSMELT, delivers process air and fuel beneath the surface of a liquid slag bath. This creates very turbulent conditions in the bath, promoting mass transfer, heat transfer, and ultimately enhancing the reaction rate. These conditions result in a high process capacity for a small furnace volume. This technology is capable of accepting a wide range of leeds with minimal feed preparation. The combination of small plant size, high capacity, minimum feed preparation, and minimum product handling, results in very low capital costs.

\subsection{Process Description}

\subsubsection{Current Waste Applications}

This technology has not been developed for waste treatment per se. Its primary application has been for the smelting of metal ores. ${ }^{1,2,3}$ Some of these applications include smelting of "metal ore" normally considered as waste by the mining industry. These "wastes" consist of low grade ores, lines, slags, and other materials that are not economical to process with conventional technology. The following list identifies the materials both metal ores and "wastes," that have been successfully processed with the SIROSMELT technology:

Tin

- Tin concentrate smelting

- Tin slag reduction

- Sulphide fuming of refractory tin ore

- Tin fume smelting

- Tin oxide fuming

Lead

- Direct lead smelting

- Lead softener slag reduction

- Recovery from lead residues

Copper

- Copper concentrate smelting

- Copper matte converting

- Copper/gold ore smelting

- Copper converter slag reduction

- Copper anode furnace slag reduction 
Nickel

- Nickel laterite smolting

- Nickel concentrate smelting

- Nickel slag reduction

- Nickel matte converting

Zinc

- Zinc fuming from blast furnace slag

- Recovery of zinc from leach residues

- Zinc sulphide smelting

Tantalum

- Stibiotantalite concentrate smelting

- Tantalum carbide sludge smelting

Silver

- Silver retort bullion cupellation

- Concentrate smelting

Gold

- Refractory gold concentrates

- Recovery from complex intermediates

These materials have been processed at rates ranging from $50 \mathrm{~kg} / \mathrm{hr}$ to 50 tonnes/hr.

\subsubsection{Theory of Operation}

Figure 4-1 provides a schematic cross section of a Sirosmelt Furnace. The furnace is a standard refractory lined vessel. Feed material is added through the top of the furnace. The Sirosmelt lance is inserted through the top of the furnace, and the offgas exits through the top of the furnace. Slag and metal are tapped from the bottom of the furnace. The exact procedure for operating the furnace deperids on the type of feed material and the treatment needs. To treat an inert waste stream, the furnace is first raised to the operating temperature by using a conventional fossil fuel burner. Then material is added to establish a molten pool of slag. Once this slag pool is established the Sirosmelt lance is lowered into the slag and fuel and oxygen are injected through the lance. During this start-up phase, the lance is raised and lowered to build up a slag layer on the exterior surface of the lance. This slag layer is maintained by the cooling effect of the gases passing through the lance. The slag layer provides insulation and protects the lanee from attack by the molten materials. After the start-up phase, material is fed through the top of the furnace, while the lance is operated continuously. Slag and metal are tapped intermittently from the furnace. 


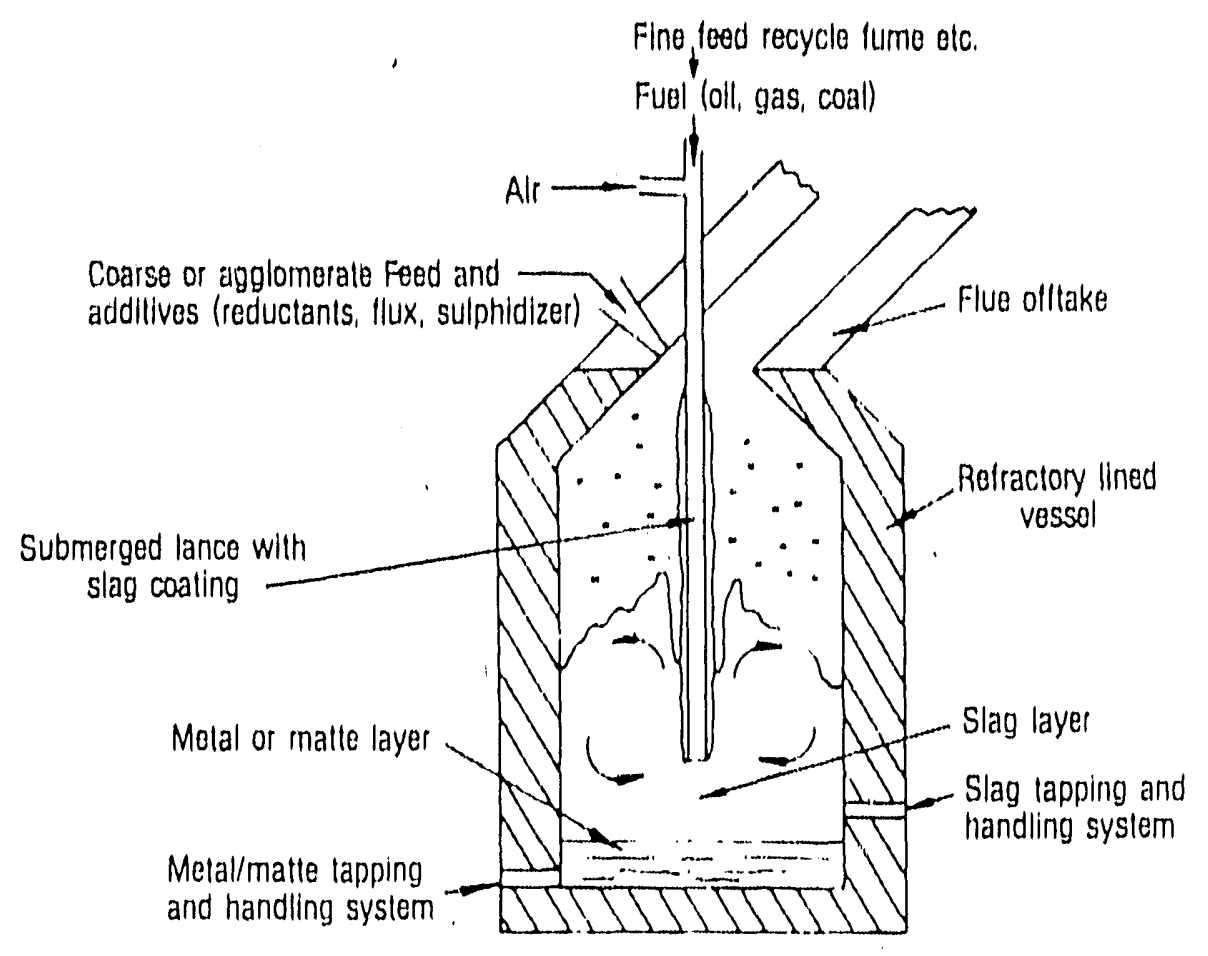

Figure 4-1. Schematic cross section of a sirosmelt furnace.

This technology results in the generation of three secondary waste streams; molten slag, molten metal, and offigas. The molten slag will be similar to slags produced by other thermal treatment processes. The molten metal produced depends on the metal content of the feed material, stoichiometry of the combustion process, and temperature of operation. During treatment of radioactive wastes, the metal produced will most likely be classified as low level radioactive waste. The offgas will have a high volume because of the use of lossil luel energy and operation at high temperatures. The olfgas will have a high particulate loading, because of the turbulent process conditions. Treatment of this offgas to remove particulate and acid gases will result in the generation of more secondary wastes. The characteristics of these will depend on the type of offgas treatment.

\subsubsection{Material and Energy Balances}

Figure 4-2 shows the process flow diagram for a hypothetical waste treatment system using the Sirosmelt lance. The system eonsists of a conventional refractory lined furnace and an air pollution control system. The Sirosmelt lance is operated on natural gas and uses oxygen enriched air (c.g., 30) $\mathrm{wt}^{\%} \% \mathrm{O}_{2}$ ) to allow more efficient operation at high temperature. The furnace operates at 260()$^{\circ} \mathrm{F}$ and the molten slag exits the furnace at this temperature. Heat loss from the furnace is estimated at $20 \%$. The offgas system removes all of the particulate as a dry solid and uses quench water to reduce the offgas temperature 10 saturation. The particulate loading in the offigas is assumed 10 be $5 \%$ of the inert material in the feed.

Figure 4-3 shows the mass flows associated with the process flow diagram of Figure 4-2. The fuel required is calculated by assuming that 880 Btu/lb is required 10 melt the incert material in the feed. This basis is similar to the values reported for the Vortec cyclone furnace. It does not necessarily represent INEL Buried Waste. The quench water flow is calculated by assuming that 


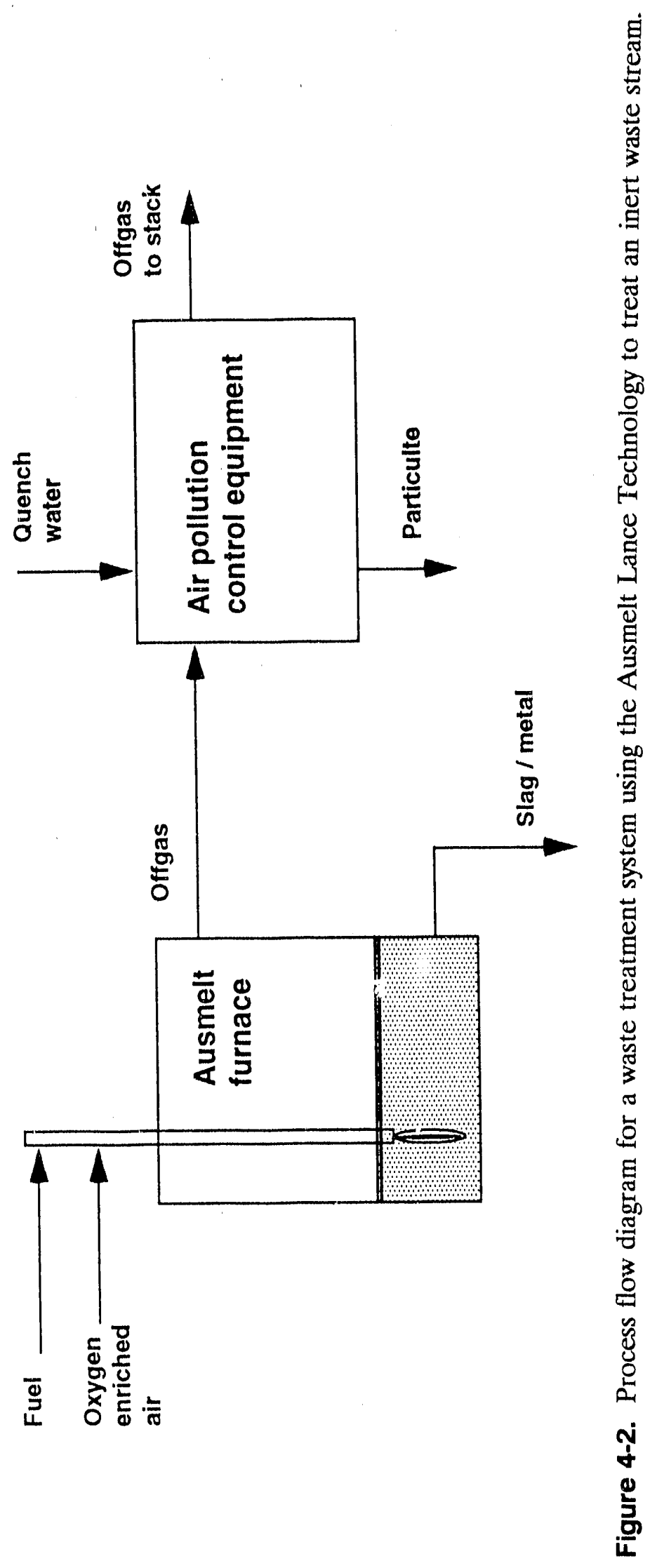




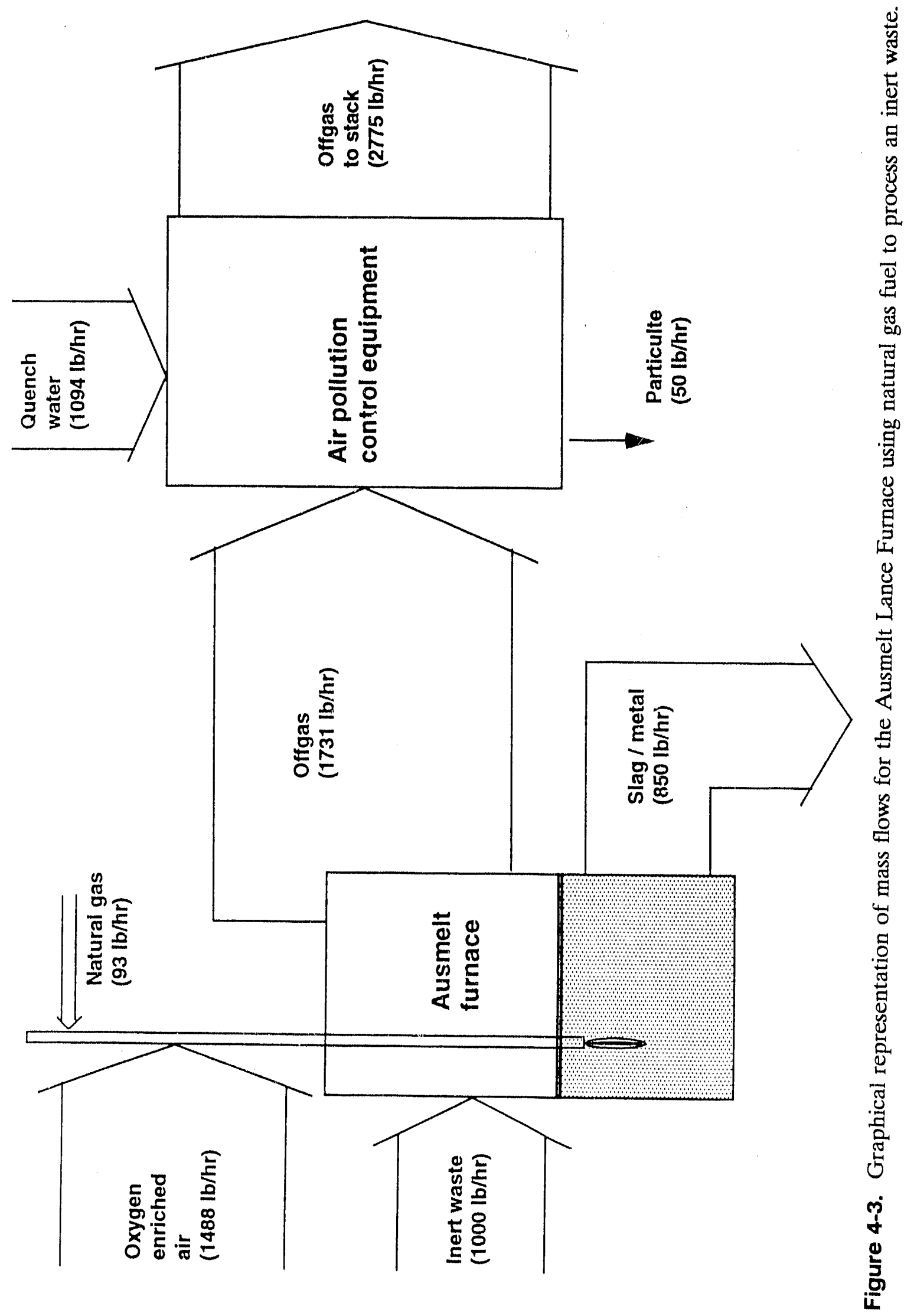


$960 \mathrm{Btu} / \mathrm{lb}$ is transferred to the water. This provides a simple approximation for an adiabatic quench. The resulting offgas temperature will be approximately $180^{\circ} \mathrm{F}$.

Figure 4-4 shows the energy flow that corresponds to the mass flow of Figure 4-3. Because this system uses fossil fuel, the amount of energy supplied in the fuel must be much greater than the energy required for melting of the feed. This is caused by the energy lost to heating nitrogen and combustion products to the process temperature. As shown in Figure 4-4, 2.0 MBtu/hr is supplied by the fossil fuel, $0.4 \mathrm{MBtu} / \mathrm{hr}$ is lost as waste heat. This leaves $1.6 \mathrm{MBtu} / \mathrm{hr}$. Only $50 \%$ of this energy, $0.8 \mathrm{MBtu} / \mathrm{hr}$, is used in melting the feed and heating the moisture in the feed to $2600^{\circ} \mathrm{F}$. Without oxygen enrichment, this process would have an efficiency of $33 \%$ instead of $50 \%$. Higher process temperatures will result in even lower efficiencies, unless the degree of oxygen enrichment is increased.

\subsection{Technology Analysis}

\subsubsection{Advantages}

This technology could potentially provide a rugged and versatile method for thermally treating a wide variety of wastes. The technology has a simple design and has been proven in large scale applications of 5 tonnes $/ \mathrm{hr}$. The process can be operated with a wide variety of fossil fuels including oil, coal, and natural gas. This technology does not appear to pose any inherent size limitations and could be developed to treat large objects (dimensions of several feet). This technology may be capable of treating heterogenous mixture of organic and inorganic materials with irregular sizes.

\subsubsection{Disadvantages}

This technology has not been developed for treatment of hazardous or radioactive wastes. This technology has not been developed for operation in a closed, tightly sealed system. The existing systems appear to have the potential for substantial fugitive emissions. High temperature operation $\left(>2500^{\circ} \mathrm{F}\right)$ requires oxygen enrichment and increases operating costs. For waste treatment the selection of an operating temperature is a tradeoff between increased fuel, oxygen, and furnace refractory costs required for higher temperatures. For operation at lower temperatures the increased slag additive costs and the decreased volume reduction associated with lower temperature operation. Because this technology is based on a highly turbulent process zone, it is likely that large amounts of particulate will be entrained in the offgas. A report on smelting of copper concentrates with the Sirosmelt lance confirms these tendencies. ${ }^{4}$ Because this technology uses fossil fuel energy, applications of this technology for high temperature melting of inert waste materials will result in large offgas volumes.

\subsubsection{State of Development}

This technology has been proved at bench, pilot, and demonstration scales for smelting of ores and concentrates. This technology has not been applied to waste processing per se. It has been used to recover metals from waste materials (e.g., discard-slags, Jarosite, and minerals processing wastes), but has not been used or developed to treat hazardous wastes. 


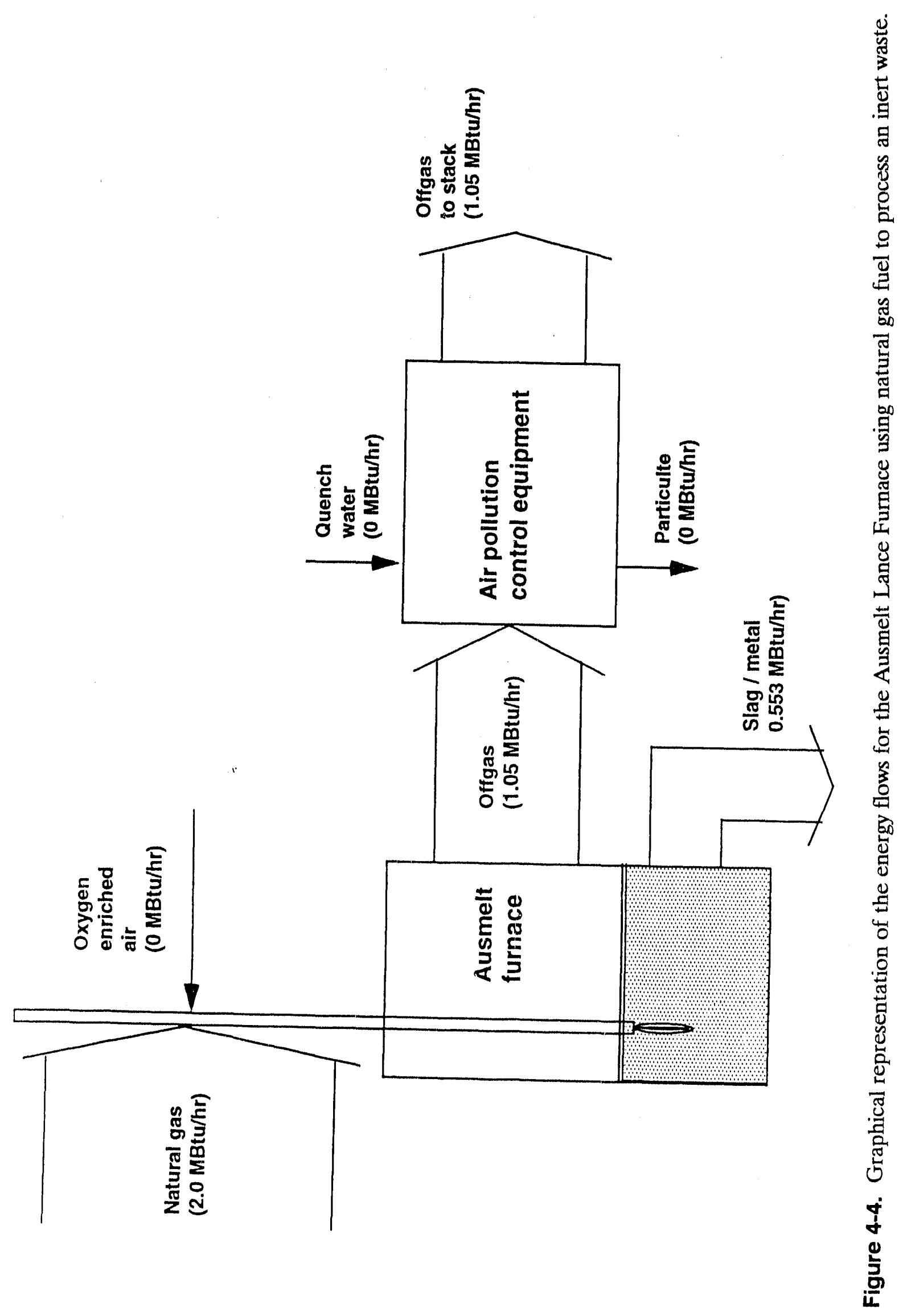




\subsubsection{Research, Development, or Demonstration Needs}

This technology will require the same development for slag chemistry as all of the melting technologies. To be considered for radioactive waste treatment, demonstrating that this process can be sealed and the furnace operated at a slightly negative pressure is necessary.

The two key areas for sealing are the Sirosmelt lance and the feed system. Sealing of the feed system is a problem that is common to all thermal treatment technologies.

\subsection{INEL Burled Waste Applications}

This technology is not appropriate for treatment of the combustible waste stream. This technology is best suited for systems with a high fraction of inert materials.

This technology is applicable to the treatment of the inert waste stream. It is likely that significant quantities of additives will be required to produce a molten slag at a reasonable operating temperature.

This technology may be applicable to both the aqueous and organic based sludges. The effect of injecting aqueous waste into this type of furnace is not known. The processing rate will probably be limited by the offgas volume handling capacity.

The technology may be applicable to the treatment of combined combustible and inert waste stream. Because this technology can be implemented at a large scale, it may be possible to treat INEL Buried Waste wastes with minimal pretreatment.

\subsection{References}

1. A. T. Hart, J. M. Floyd, and S. R. Richards, "Modification of Iron Blast Furnace Slag Using Sirosmelt Technology," The AusIMM, Illawarra Branch, Utilization of Steel Plant Slags Symposium, Feb. 1979, pp. 59-63.

2. K. A. Foo and J. M. Floyd, "Development of the Matte Fuming Process for Tin Recovery from Sulphide Materials," Lead-Zinc-Tin '80, AIME 91980), pp. 786-800.

3. J. M. Floyd, N. C. Grave and B. W. Lightfoot, "Small Pilot Plant Trials of Sirosmelt Cupper Smelting," Australia-Japan Extractive Metallurgy Symposium, Sydney, 1980, pp. 63-74.

4. L. E. Anderson, J. M. Floyd, B. W. Lightfoot, and R. G. Muller, "Smelting of Olympic Dam Copper Concentrates Using Sirosmelt Technology," Complex Sulfides: Processing of Ores, Concentrates, and By-Products, TMS-AIME Falls Extractive Meeting, San Diego, Nov. 10-13, 1985, pp. 623-634. 


\section{MOLTEN METAL BATH TECHNOLOGY}

The term molten metal bath refers to a treatment approach that uses a pool of molten metal as the medium to transfer heat to waste materials to break down the organics and vitrify the inorganics into a slag material. The slag is drawn off the top of the melt and the bath is maintained at a relatively constant level by tapping off or adding metal, as required. Steel is typically used as the bath material, but any of a variety of metals could be used to tailor the process to meet specific treatment requirements.

\subsection{Development History}

Development of the technology is relatively recent. U.S. Steel (U.S.S.) developed a molten metal bath technology between 1982 and 1986 termed the catalytic extraction process (CEP). ${ }^{1}$ A technology innovation group at U.S.S developed the process looking for ways to use the stored energy in the molten steel and slag in the steel plant's processing units. The group concluded that they could use the molten metal as a solvent and run high temperature chemical reactions on waste materials and byproducts. U.S.S. received broad patent coverage for the technique. However, U.S.S. opted not to pursue it, and transferred the rights in 1989 to a new development company, Molten Metal Technology (MMT) of Cambridge, Massachusetts, via the Massachusetts Institute of Technology (MIT). ${ }^{1}$

MMT subsequently formed alliances with a variety of commercial companies to help market the technology. The technical entities that have agreements in place with MMT include LAir Liquide of France and DuPont and Rollins Environmental Services of the U.S. The CEP is illustrated in Figure 5-1.

A separate molten metal bath project was initiated in 1986 as a joint German/Swedish (KFA$\mathrm{KTH}$ ) investigation. ${ }^{2,3}$ The project examined various metal industry processes for use in the destruction of hazardous wastes. This investigation leaned toward adapting the iron bath coal gasification process, rather than the scrap metal conversion process that MMT is pursuing, though the processes are very similar. This project was reported as a paper study and is in the early pilot demonstration stage.

Applicable waste treatment data on this process are extremely limited. MMT is treating the details of its process as proprietary, making assessment of the technology highly speculative. However, some general conclusions can be drawn.

\subsection{Process Description}

\subsubsection{Current Waste Applications}

The application for which the technology was originally intended was introduction of chemical energy into a scrap steel converter to increase the capacity for scrap steel processing. This was accomplished by adding carbon from various waste forms, such as waste oil and tires, to reduce the iron oxide and produce iron and carbon monoxide. MMT subsequently applied the process to a wide 


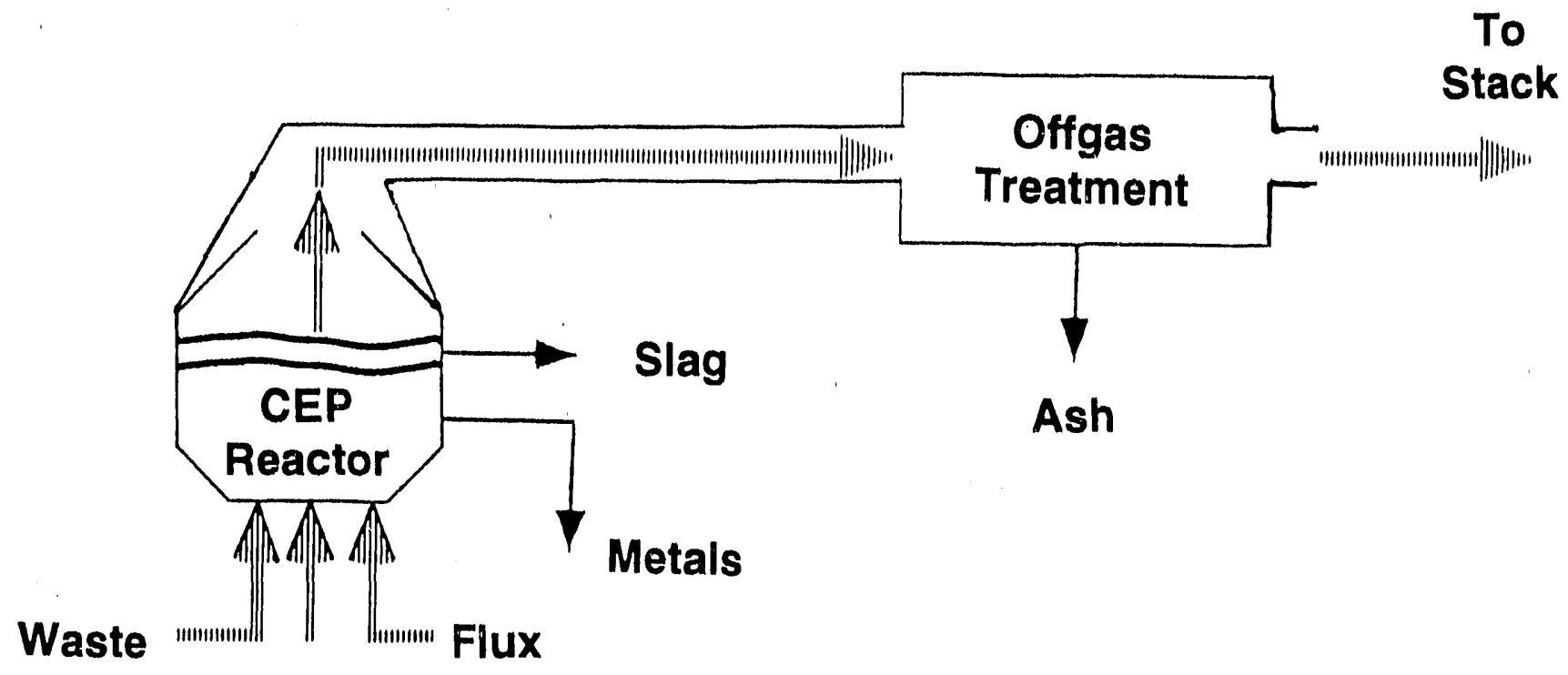

\section{Oxygen}

Figure 5-1. Simplified flow diagram for catalytic extraction process.

variety of chemical by-products and industrial waste materials. The technology primarily aimed at the resource recovery market, where valuable materials can be recovered from a waste or by-product stream within an existing commercial process, thereby avoiding RCRA regulations. ${ }^{4}$ Examples include the recovery of valuable metals such as nickel from a nickel contaminated organic stream, recovery of cobalt from spent catalysts, or generation of synthesis gas from hydrocarbon bearing wastes. Some work has also been done on waste processing to demonstrate destruction of organics such as PCB.

The preferred means of feeding is by injecting liquid, gas, or fluidized solid waste into the bottom of the metal bath along with reagent gases and fluxes. However, the vendor reports that large solids such as whole PCB transformers were fed over the bath from a conveyer system.

\subsubsection{Theory of Operation}

Catalytic extraction processing utilizes standard "off the shelf" equipment from the steel processing industry. The process vessel is a steel converter, which is an enclosed, airtight cylinder with dimensions that can vary widely to yield the combination of surface area and retention time required for specific waste characteristics.

To initiate the process, the metal catalyst, which is typically stecl, is melted in the reactor by one of three standard methods: induction heating, electric arc, or plasma arc. Of the three methods, plasma are is the least used. Temperatures in the $2500-3500^{\circ} \mathrm{F}$ range are used, with $30000^{\circ} \mathrm{F}$ most typical. A reducing atmosphere is maintained in the reactor.

Waste material in the form of gas, liquid, sludge, or solid is introduced into the molten metal bath beneath the surface, generally utilizing a pneumatic transport approach for the solids. Because 
of rapid heat transfer from the molten steel to the waste, the waste material dissociates into its elemental constituents. The dissociated atoms become evenly distributed throughout the bath by the natural convection currents present. Oxygen is injected into the bath to strip the carbon absorbed by the steel. This reaction forms carbon monoxide.

The molten inorganic material (slag) introduced by the waste rises to the top of the bath and is eventually skimmed or tapped off. The slag acts as an insulator to increase the bath's thermal efficiency and as a primary scrubber to remove such materials as volatile heavy metals, phosphates, and sulphur. Other reactants may be added to the bath to optimize slag chemistry. Typically, the slag is cast into shapes for ease of handling, though it can be quenched and collected in a water bath where the thermal shock creates a relatively small aggregate waste form. The metal components, which are heavier than the slag, collect in the metal bath and are tapped separately from the slag. If the metals are mixed, subsequent processing would be necessary for separation and recovery of the metals of interest. ${ }^{1}$

The CEP design does not provide for secondary combustion of organics because MMT believes complete organic destruction will occur in the bath and in the high temperature reactor space above it. The KFA-KTH pilot plant will have either oxygen injection in the reactor above the bath or a separate secondary combustion chamber. ${ }^{2}$ The CEP unit could be provided with a secondary chamber as well.

\subsubsection{Material and Energy Balances}

Figure 5-2 is a graphical representation of the mass flow for a molten bath furnace treating $1000 \mathrm{lb} / \mathrm{hr}$ of an inert waste. In this case, the waste contains no combustible material, however, some offgas is generated from the vaporization of moisture in the feed. The only gases entering the furnace are from air leaks and purges on the feed system. Electrical energy is supplied through submerged electrodes or induction heating. This process results in minimal offgas volume. During the processing of actual waste, the offgas flow is likely to be higher because of small amounts of organic materials in the feed. Also, decomposition of inorganic materials such as nitrates and carbonates will release gases.

Figure 5-3 is a graphical representation of the energy flow for the molten metal bath process shown in Figure 5-2. Approximately 77\% of the electrical energy input is used to melt the solid inert material. The remaining energy is lost as heat through the furnace walls and as hot offgas.

Treatment of a waste with even a small organic content will dramatically alter the material and energy balances. Waste with only $8 \%$ carbon, resulting in a heating value of $1120 \mathrm{Btu} / \mathrm{lb}$, would release energy equivalent to the electrical input shown in Figure 5-3. Complete combustion of this waste would result in 10 times the offgas volume. Thus, although this is a low volume offgas process, the offgas flow rate can easily be dominated by a small amount of combustible material in the feed. 


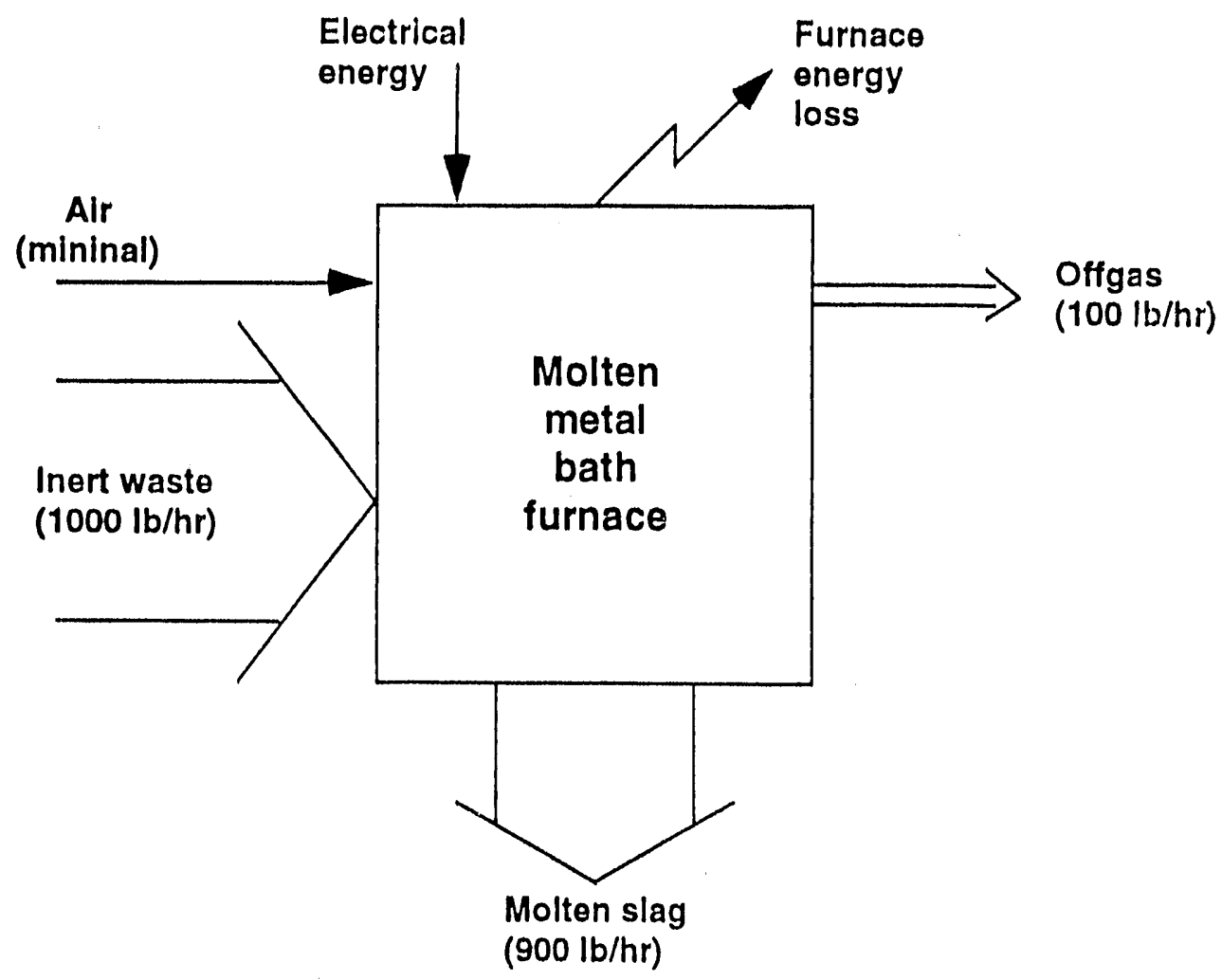

Figure 5-2. Graphical representation of mass flows for a simplified molten metal bath process with inert feed $(\mathrm{HHV}=0.0 \mathrm{Btu} / \mathrm{b})$.

\subsection{Technology Analysis}

\subsubsection{Advantages}

The CEP operates at high temperatures and with sufficient residence time within the bath to achieve highly efficient destruction of organics. The high energy density of the molten metal allows shorter residence times for complete destruction. The high temperature operation results in vitrification of inorganic solids and produces a slag that is likely to be a highly stable and leach resistant waste form. Operation of the technology in a reducing mode minimizes the high $\mathrm{NO}_{\mathrm{x}}$ that would otherwise be generated by the high temperatures. The technology has a long history of the building and operation of large scrap steel converters. The use of oxygen injection instead of air results in low volumes of offgas emissions and the introduction of waste below the surface of the bath results in high particulate retention and thus low offgas carryover. The large thermal mass of the metal bath results in a more stable and uniform temperature environment than open flames and a greater likelihood of complete organic destruction. Nonflame combustion ensures that the offgas is free of contamination from products of incomplete fuel combustion.

CEP reactor vessels are simple and compact. As in most vitrification devices, the fly ash may be returned to the reactor for reprocessing. Radiologically contaminated metal could be used for the 


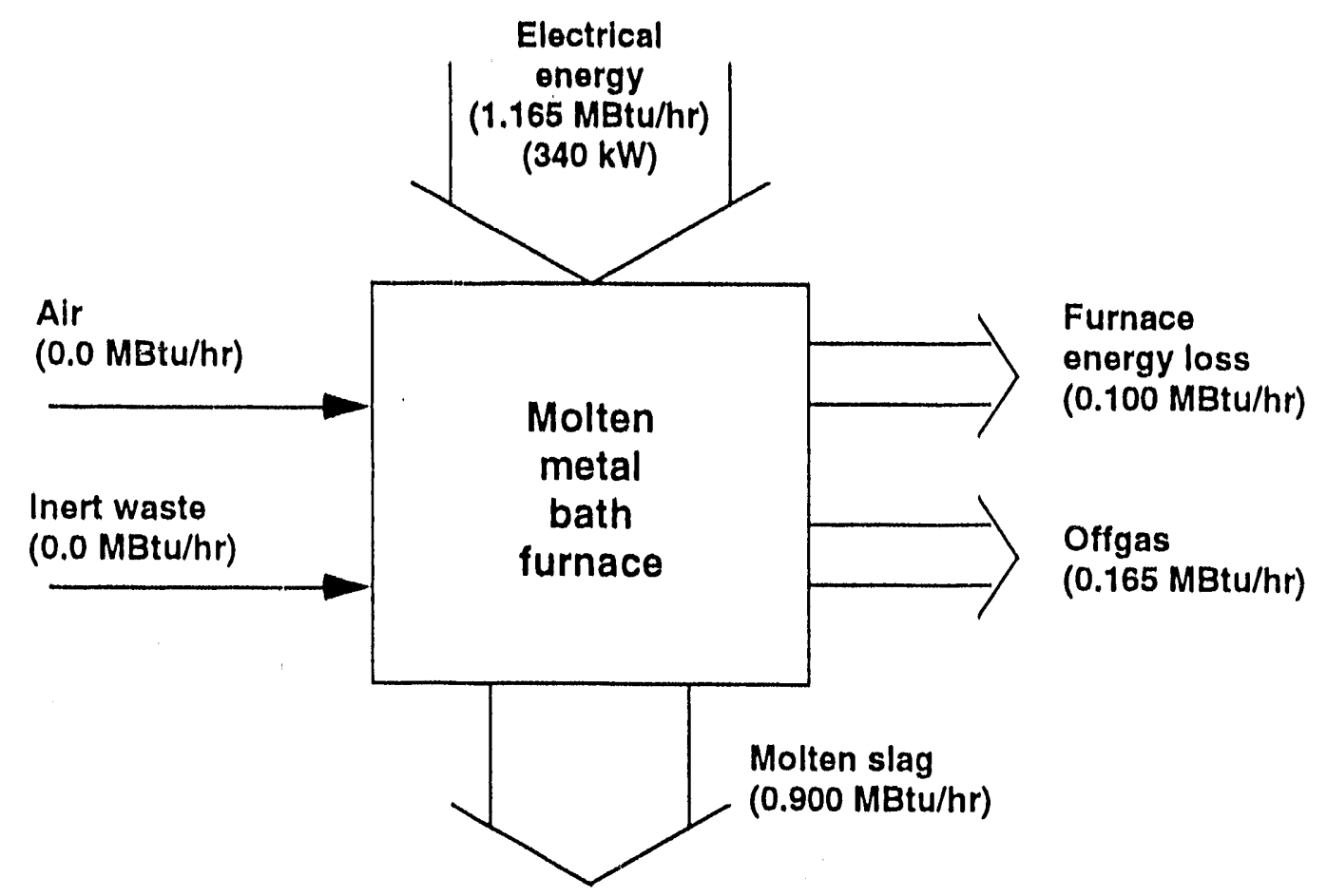

Figure 5-3. Graphical representation of energy flows for a simplified molten metal bath process with inert feed $(\mathrm{HHV}=0.0 \mathrm{Btu} / \mathrm{lb})$.

bath, providing a method of decontamination, since radionuclides tend to migrate to the slag and volume reduction by eliminating void spaces.

\subsubsection{Disadvantages}

The high operating temperatures of the CEP will result in relatively high volatilization of heavy metals and radionuclides into the offgas stream, requiring special attention for the removal of these constituents in the offgas treatment system.

Solid waste must be size reduced extensively for subsurface injection, or else dropped into the bath from above, which may reduce the effectiveness of the process to completely treat the waste (i.e., the waste may volatilize and be carried directly into the offgas without complete destruction). Introduction of significant quantities of noncombustible liquids or wet solids directly into the metal bath has the potential of causing a steam explosion. Slag chemistry is dependent on waste characteristics and may be difficult to optimize with a heterogeneous waste feed. If the metal in the bath is not radioactively contaminated to start with, it will be considered contaminated after exposure to mixed waste. 


\subsubsection{State of Development}

The development work performed at U.S.S. between 1982 and 1986 verified the principles of operation and could be considered bench scale development, though leed rates of up to 22,000 tons/yr were demonstrated on a variety of carbon-containing streams. The German/Swedish effort is in the pilot demonstration stage, but no data are available on demonstration results.

MMT claims its technology is commercially available and has developed designs for facilities ranging in capacity from 5,000 to $100,0(0)$ tons/yr. However, no commercial units have been constructed to date. Realistically, the technology will require actual waste processing at pilot scale before it can be considered commercially available.

\subsubsection{Research, Development, or Demonstration Needs}

Primary research needs to demonstrate the technology's effectiveness in hazardous waste destruction. Other needs include the following: investigation of partitioning of radionuclides and heavy metals in the metal bath and slag, determination of slag chemistry sensitivity to variations, in waste content, and leachability characteristics of the slag. The technology has not been demonstrated for soil applications.

\subsection{Potential for INEL Applications}

The potential application of this technology to the INEL buried wastes is difficult to assess given the state of development. If the technology proves to be effective at processing large solid wastes without extensive pretreatment by introduction into the metal bath from above the surface, then it is likely that most buried wastes could be processed. However, the technology has been demonstrated to be most effective when the waste is gaseous, liquid, or fluidized solid fines and is injected under the bath. Extensive pretreatment of most buried wastes would be required to yield solid fines capable of fluidization in order to pneumatically transport the solids for introduction into the molten metal bath beneath the surfaces.

\subsection{References}

1. Smith, Jeffrey D., "Molten Metal Technology," EI Digest, pp. 8-13, July 1991.

2. Axelsson, Carl-Lennart, "KFA-KTH Joint Investigation on a Process for Hazardous Waste Destruction in an Iron Melt," Stockholm, Sweden, May 1988.

3. Zimmer, Erich, "Treatment of Hazardous Wastes in an Iron Melt," KFA Julich GMbH, Julich, Germany, September 1988.

4. Yates, Ian C. and Johnston, James E., "Resource Recovery With Catalytic Extraction Processing," Environmental Waste Management, pp. 30-31, May 1991. 

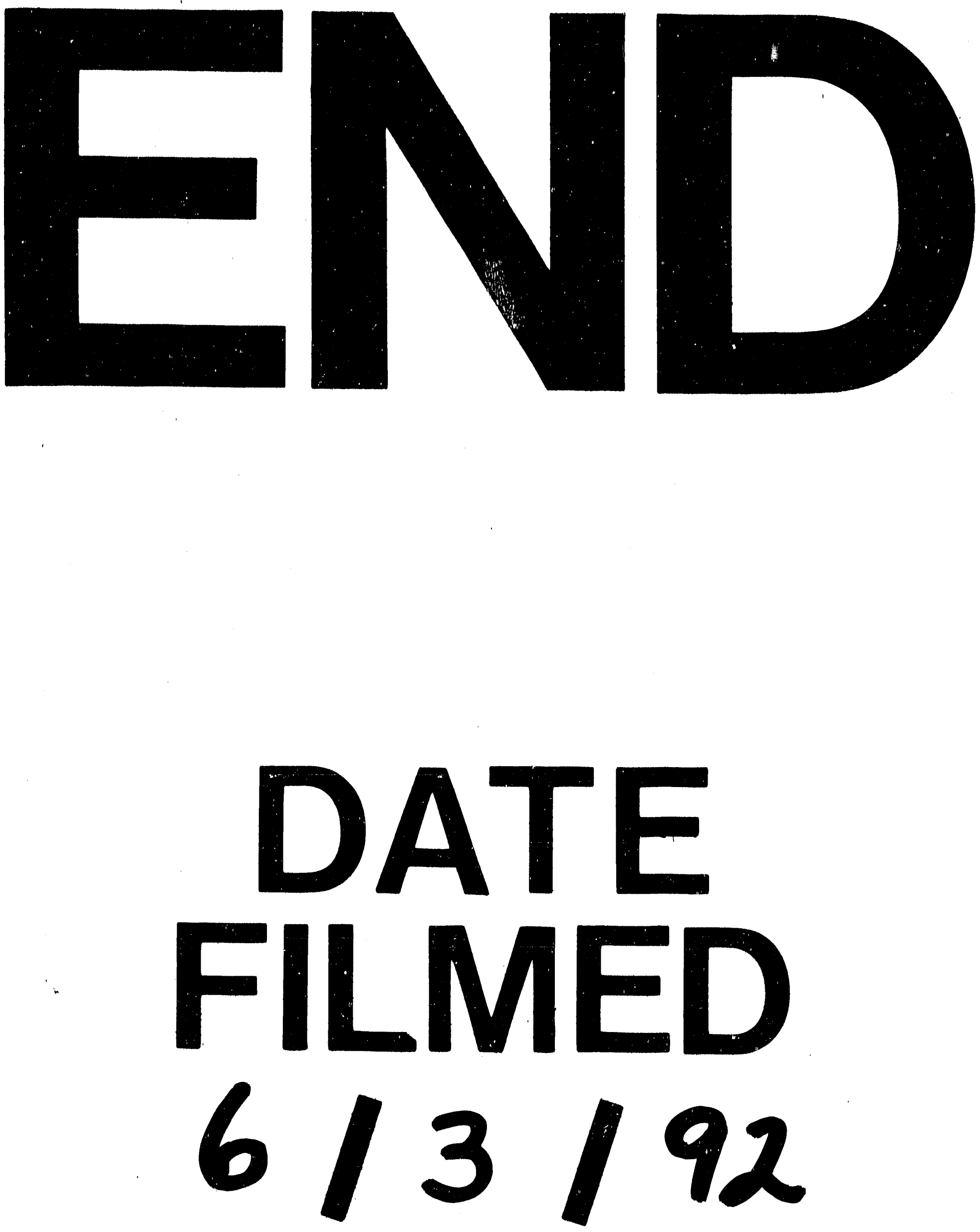
